Atmos. Chem. Phys. Discuss., doi:10.5194/acp-2016-673, 2016

\title{
Synoptic perspectives on pollutant transport patterns observed by satellites over East Asia: Case studies with a conceptual model
}

Hyun Cheol Kim ${ }^{1,2}$, Soontae Kim ${ }^{3}$, Seok-Woo Son ${ }^{4}$, Pius Lee ${ }^{1}$, Chun-Sil Jin ${ }^{5}$, Eunhye Kim ${ }^{3}$, Byeong-Uk

$5 \mathrm{Kim}^{6}$, Fong $\mathrm{Ngan}^{1,2}$, Changhan Bae ${ }^{3}$, Chang-Keun Song ${ }^{7}$, and Ariel Stein ${ }^{1}$

1 Air Resources Laboratory, National Oceanic and Atmospheric Administration, College Park, MD

2 Cooperative Institute for Climate and Satellites, University of Maryland, College Park, MD

3 Department of Environmental and Safety Engineering, Ajou University, Suwon, Korea

4 Seoul National University, School of Earth and Environmental Sciences, Seoul, Korea

105 National Centers for Environmental Prediction, National Oceanic and Atmospheric Administration, College Park, MD

6 Georgia Environmental Protection Division, Atlanta, GA

7 National Institute of Environmental Research, Incheon, Korea

Correspondence to: Hyun Cheol Kim (hyun.kim@noaa.gov)

15 Abstract. We demonstrate that daily pollutant transport patterns in East Asia are visible from satellite images when inspected with corresponding synoptic weather analyses. Transport pathways of air pollutants in East Asia are investigated using satellite observations, surface weather charts, and chemical-transport model simulations. It is found that during cool season (fall to spring), pollutant transports in East Asia are largely determined by synoptic weather patterns associated with high pressure system over southern China, which is extended from the Siberia High, and low pressure system over Manchuria, which is initiated by Altai-Sayan cyclogenesis. Based on the relative location and strength of these weather systems, three types of synoptic weather patterns that may contribute to pollutants transport in East Asia, especially in China and Korea, are identified: i.e., (1) a strengthening of the Siberian High and its southeastward propagation; (2) a high-pressure system over southern China followed by a frontal passage associated with a northern low-pressure system; and (3) a stagnant high-pressure system over southern China. For all three patterns, the high-pressure system in southern China is essential for the development of regional air pollution, while frontal activities associated with low-pressure system provide a forcing mechanism to transport those pollutants eastward or southeastward. Observed and simulated surface PM distributions show good agreement in both aerosol optical depth and NO2 column density further implying that anthropogenic emissions also contribute to regional events of high surface PM concentrations. It is argued that the quasi-periodic migration of synoptic weather systems in East Asia works as an efficient pump of pollutants; i.e., regional air pollutions developed under highpressure systems are transported downstream by low-pressure systems. 
Atmos. Chem. Phys. Discuss., doi:10.5194/acp-2016-673, 2016

Atmospheric

Manuscript under review for journal Atmos. Chem. Phys.

Chemistry

Published: 9 September 2016

(c) Author(s) 2016. CC-BY 3.0 License.

and Physics

(c) $\underset{\mathrm{BY}}{\mathrm{B}}$

\section{Introduction}

Regional air quality is a rising concern in East Asia (e.g. China, Korea, and Japan), where the chemical environment has rapidly changed due to fast economic growth and industrialization, especially in China (Guan et al., 2009; Park and Kim, 2014; Richter et al., 2005; Zhang et al., 2007). The rapid and varied industrial development, the use of coal for power 5 generation, and the increasing number of vehicles on the roads have increased the emission of pollutants in the region, especially particulate matter (PM) and its precursors. In January 2013, the highest instantaneous concentration of $\mathrm{PM}_{2.5}$ reached over $1000 \mu \mathrm{g} / \mathrm{m}^{3}$ in heavily polluted areas of Beijing (Zhang et al., 2014). Woes continue as of 2015, with levels of daily $\mathrm{PM}_{2.5}$ concentration at the US embassy in Beijing recorded as high as $450 \mu \mathrm{g} / \mathrm{m}^{3}$ (February 25, 2014) and $537 \mu \mathrm{g} / \mathrm{m}^{3}$ (December 25, 2015) (http://www.stateair.net/web/post/1/1.html), almost 20 times higher than the standard recommended by

10 the World Health Organization (WHO, 2005).

Korea also has similar challenging and ongoing regional air-quality issues, especially in the Seoul Metropolitan Area (SMA), the most populated and industrialized region in Korea. The Korean government legislated a special Act in 2005 implementing a series of strict policies to reduce air-pollutant emission, with the goal to attain $\mathrm{PM}_{10}$ and nitrogen dioxide $\left(\mathrm{NO}_{2}\right)$ concentration levels of $40 \mu \mathrm{g} / \mathrm{m}^{3}$ and $22 \mathrm{ppbv}$, respectively, by 2014, compared to $69 \mu \mathrm{g} / \mathrm{m}^{3}$ and $38 \mathrm{ppbv}$, respectively,

15 in 2003 (UN, 2006). Continuous efforts from the Korean government and society have indeed improved the annual mean $\mathrm{PM}_{10}$ (WMO, 2012); however, one yet-unsolved issue is that the SMA still experiences frequent episodic regional pollution events and continuous degradation of visibility, especially during the winter (Oh et al., 2015). Recent studies have suggested that the long-range transport of emissions or pollutants from neighboring countries-especially from China- has partly contributed to the SMA's air pollution problem (Jeong et al., 2011; Lee et al., 2008; Lee et al., 2014; Moreno et al., 2012;

20 Ou-Yang et al., 2013; Verstraeten et al., 2015). The mechanism of these transport pathways, however, has not been fully understood yet.

In this study, we revisit the relationship between synoptic weather patterns and the development and transport of air pollutants in East Asia (Ding et al., 2009; Lee et al., 2011b, 2013; Oh et al., 2015; Zhang et al., 2016). Only the cool season (fall to spring) is considered as air pollutions are severe in this season while pollutants are quickly washed out during Asian

25 summer monsoon period. Unlike in previous studies, all available satellite datasets, synoptic weather maps and chemistry transport model output in the region are used. In order to directly compare datasets with varying resolutions, all data are carefully re-projected on the model grids using newly developed geospatial data processing technique.

We begin with a conceptual model that is based on the cool season synoptic weather systems in East Asia. Section 2 presents three dominant synoptic weather patterns, potentially associated with pollutant transport in East Asia, that are classified by

30 considering the location and strength of high-pressure and low-pressure systems in the surface weather maps. In Section 3 , short descriptions of satellite and model data used in this study are provided. In Section 4, we illustrate the three synoptic weather patterns that may control regional-scale pollutant transport patterns, presenting satellite observations and model 
Atmos. Chem. Phys. Discuss., doi:10.5194/acp-2016-673, 2016

Atmospheric

Chemistry

Manuscript under review for journal Atmos. Chem. Phys.

Published: 9 September 2016

(c) Author(s) 2016. CC-BY 3.0 License.

and Physics

Discussions

(c) $\underset{\mathrm{BY}}{\mathrm{B}}$

simulations. The possible contribution of Chinese anthropogenic emissions to surface PM concentrations in Korea is also briefly discussed. Finally, summary and conclusions are presented in Section 5.

\section{Classification of pollutant transport patterns in East Asia}

The synoptic weather patterns have been extensively examined to identify transport pathways of pollutants and/or of their

5 precursors, including Asian Dust, in East Asia (Chun et al, 2001; Chung, 1992; Husar et al., 2001; Iwasaka et al., 1983; Kim et al., 2005; Kim, 2008; Merrill et al., 2004; Sun et al., 2013; Tan et al., 2012). Among others, Kim et al. (2001a, 2001b) studied the transport and evolution of wintertime Asian Dust observed in Korea, and the transport of $\mathrm{SO}_{2}$ and aerosol over the Yellow Sea. Kim et al. (2005) used Hybrid Single Particle Lagrangian Integrated Trajectory (HYSPLIT, Stein et al., 2015) back-trajectories and performed a cluster analysis during the ACE-Asia campaign.

10 The pollutant transport patterns are important not only for regional air quality but also for global climate variability and change. Wang et al. (2014), who used a multiscale, global aerosol/climate model to assess the effects of Asian pollution outflows on regional climate and global atmospheric circulation, demonstrated that long-range transport of Asian pollutants and the resulting variations in aerosol optical depth, cloud-droplet concentration, and cloud- and ice-water paths can enhance cloud radiative forcings and increase precipitation and poleward heat transport. This clearly suggests that pollutant transport

15 in East Asia is not simply a regional air quality issue. However, the processes that leads to the transport, transformation, and removal of pollutants in East Asia still remain uncertain (Dickerson et al., 2007).

\subsection{Synoptic weather systems in East Asia}

During the Northern Hemisphere cool season, synoptic weather systems in East Asia are mainly characterized by the persistent Siberian high and the transient development of low-pressure systems on the lee side of mountains. A simplified

20 diagram, highlighting migratory synoptic weather systems in northeast Asia, is shown in Figure 1.

The Siberian High, which is primarily formed and maintained by intense surface cooling, is quite persistent during the cool season (Cohen et al., 2001; Gong \& Ho, 2002; Wu \& Wang, 2002). However, it also exhibits significant intra-seasonal variability. An episodic expansion of the Siberian High deep into southern China often causes a cold surge in East Asia (Compo et al., 1999; Garreaud, 2001; Park et al., 2013). Such an expansion of continental high-pressure system, along with migrating low-pressure systems in northern China has been considered to be a dominant pathway driving Asian pollutions off the continent. The associated cold advection also helps gas-to-particle heterogeneous processes to produce more secondary products in terms of PM concentrations (Behera and Sharma, 2010).

A prevailing high-pressure system, or near-surface anticyclone, is known to play an important role in the development of local air pollution. In general, high-pressure system accompanies a clear sky, calm wind, and subsiding air, lowering the 30 chances of pollutants being washed out by precipitation or blown away by strong winds (Chen et al., 2008; Cheng et al., 2007; Frioud et al., 2003; Im et al., 2008; Tai et al., 2010; Wei et al., 2011). The relative location of high-pressure system 
Atmos. Chem. Phys. Discuss., doi:10.5194/acp-2016-673, 2016

Atmospheric

Manuscript under review for journal Atmos. Chem. Phys.

Chemistry

Published: 9 September 2016

(c) Author(s) 2016. CC-BY 3.0 License.

and Physics

Discussions

(c) (i)

with respect to the source regions of air pollutants is also important (Wong et al., 2007). When the high-pressure system resides near the southeastern China or the Yellow Sea, that is south of the heavily polluted areas (e.g., the Beijing-TianjinHebei region), the anticyclonic outflow on the northern side of the high-pressure system, that is westerly or northwesterly, creates the perfect conditions for transporting highly polluted air to Korea and Japan.

5 Regional air pollution is also influenced by the travelling low-pressure systems or cyclones. In East Asia, Altai-Sayan cyclones, which are initiated over the Mongolian Plateau on the lee side of the Altai-Sayan Mountains (Chen et al., 1991), tend to travel southeast or east-southeast towards northeast China or Manchuria. These transient weather systems are known as one of the major processes initiating Asian Dust, since their arid characteristics may trigger wind erosion across a wide area and the associated cold frontal activities may lift dust from the surface (Chung, 1992). Likewise, Liu et al. (2003), who

10 examined carbon monoxide pathways from chemistry transport model simulations and aircraft measurements from the Transport and Chemical Evolution over the Pacific (TRACE-P) mission, also demonstrated that the major process driving Asian pollutions outflow in the spring is frontal lifting at the leading edge of southeastward-moving cold front and transport in the boundary layer behind the cold front. Ding et al. (2015) also demonstrated uplifting of CO from biomass burning and anthropogenic sources to the free troposphere in East Asia, using satellite, trajectory dispersion model and global chemistry

15 transport model.

However, unlike high-pressure system, an intensified low-pressure system plays a complicated role in the regional air quality because it also operates as a scavenging and cleaning process for most primary and secondary anthropogenic pollutants (e.g., Wei et al., 2011b). Therefore, determining the relative location and timing of these systems is crucial to identify the pollutant transport patterns and their impact on regional air quality. In the next section, we conceptually classify the pollutant tran sport

20 patterns in East Asia, by considering the relative location and intensity of high- and low-pressure systems.

\subsection{Conceptual classification}

In this section, we classify the pollutant transport patterns in East Asia, focusing on China and Korea. We first start with a conceptual understanding of regional flow patterns and emission source locations. This approach focuses on more conceptual and empirical understanding (based on daily forecast experiences), rather than numerical classification. As shown later, inspection of daily variations of Aerosol Optical Depth (AOD) and $\mathrm{NO}_{2}$ column density from satellite images, hourly variations of $\mathrm{AOD}, \mathrm{NO}_{2}$ vertical column density, and $\mathrm{PM}$ distributions from chemistry transport model, and surface weather map analyses reveals that the strength and location of anticyclonic systems over southern China (usually expanded from the Siberian High) and those of cyclonic systems over Manchuria (initiated by Altai-Sayan cyclogenesis) are the two major components that determine regional pollutant transport patterns. Objective clustering analyses in the previous studies (Kim et

30 al., 2005; Kim et al., 2014; Lee et al., 2011; Park et al., 2013) are also carefully considered. Kim et al. (2005) used cluster analysis of HYSPLIT backward trajectories arriving at the Gosan site in Jeju island, Korea, to classify five pollutant transport patterns. Their study suggested that except for Cluster 1, which originates from the Pacific region, $78.3 \%$ of trajectories come through westerly (Cluster 2, 6.7\%) or northerly (Clusters 3, 4, and 5, together 71.7\%). Lee et al. (2011) 
Atmos. Chem. Phys. Discuss., doi:10.5194/acp-2016-673, 2016

Manuscript under review for journal Atmos. Chem. Phys.

Chemistry

Published: 9 September 2016

(c) Author(s) 2016. CC-BY 3.0 License.

and Physics

Discussions

(c) $($ P)

used FLEXTRA trajectory model to classify 254 trajectories during high PM concentration events in Korea into the three types: i.e., long-range transport type (28\%), in-between type (41.3\%), and local type (30.7\%). These types are compatible with the classification types used in this study.

Conceptual classifications of synoptic weather patterns, that are likely associated with pollutant transport in China and

5 Korea, are shown in Figure 2. Based on sea level pressure (SLP), the following three types are identified: i.e., (1) a strengthening of the Siberian High and its southeastward expansion or propagation (Figure 2a); (2) a high-pressure system over southern China, followed by a cold frontal passage associated with a low-pressure system over northern China (Figure 2b); and (3) a stagnant high-pressure system over southern China or near the Yellow Sea (Figure 2c). In all cases, westerly or northwesterly flow near the surface is crucial for the development of pollutant events in eastern China and Korea (Chen et

10 al., 2008; Lee et al., 2013). In (2), Manchurian low-pressure systems (e.g., those formed by Altai-Sayan cyclogenesis) provide a forcing mechanism for pollutant transport and/or cleaning at the dissipation stage of high-pollutant episodes.

In East Asia, travelling synoptic weather systems are very common in cool season because of baroclinic instability (Park et al., 2013). When a high-pressure system prevails, it provides favorable meteorological conditions for the development of high-pollution events. On the other hand, low-pressure systems, especially those with strong cold frontal activity, push continental (e.g., Chinese) pollutants out to neighboring countries or to the western Pacific. Each synoptic weather pattern is discussed in more detail in Section 4 with observational evidences.

\section{Data and Methodology}

Both chemical transport model outputs and observational datasets are analyzed for the period of November 2012 to May 2014. As noted earlier, only the two cool seasons, November to May, are considered.

\section{3.1 Synoptic weather chart and surface $\mathbf{P M}_{10}$ data}

Surface $\mathrm{PM}_{10}$ concentrations and meteorological observations (e.g., wind speed and surface pressure) were obtained from the NIER and KMA, respectively. Three-hourly surface weather charts were also obtained from KMA. Close investigation of surface weather charts and satellite datasets is essential to understand the role played by synoptic weather systems in the development and transport of surface air pollutions. This kind of analysis is not very common in the literature because operational surface weather maps are typically provided as graphic files. In this study, we utilized a graphical technique to blend satellite images or model output with KMA weather charts. This composite technique, which is based on a Geographic Information System (GIS) georeferencing technique, is useful when only graphical analyses, taken from different institutions, are available without digitized data sets. For a technical note about this technique, refer to the Appendix. 
Atmos. Chem. Phys. Discuss., doi:10.5194/acp-2016-673, 2016

Atmospheric

Chemistry

Manuscript under review for journal Atmos. Chem. Phys.

Published: 9 September 2016

(c) Author(s) 2016. CC-BY 3.0 License.

and Physics

Discussions

(c) $\underset{\mathrm{BY}}{\mathrm{B}}$

\subsection{Satellite data}

Various satellite and in-situ observations are analyzed in the present study. They include Moderate Resolution Imaging Spectroradiometer (MODIS) Aerosol Optical Depth (AOD), Global Ozone Monitoring Experiment (GOME)-2 and Ozone Monitoring Instrument (OMI) tropospheric $\mathrm{NO}_{2}$ vertical column density (VCD), surface $\mathrm{PM}_{10}$ concentrations obtained from

5 the National Institute of Environmental Research (NIER), and weather maps from Korea Meteorological Administration (KMA). Key aspects of each datasets are briefly described below.

MODIS AOD: The MODIS aerosol product globally monitors ambient aerosol optical properties, such as optical thickness and aerosol size distribution, over the oceans and continents (http://modis-atmos.gsfc.nasa.gov/MOD04_L2/index.html). Daily level 2 products are archived and utilized to generate AOD for model grid cells. We used both Terra and Aqua

10 products (MOD04 \& MYD04 collection 6; Levy et al., 2013), which overpass at 10:30 am and 1:30 pm local times, respectively, with $10 \mathrm{~km}$ x $10 \mathrm{~km}$ horizontal resolution.

NO2 VCD: The anthropogenic emissions fluxes are estimated by using GOME-2 and OMI tropospheric $\mathrm{NO}_{2} \mathrm{VCD}$, retrieved by the Royal Netherlands Meteorological Institute (KNMI). The GOME-2 sensor, which is onboard the EUMETSAT MetOp-A and MetOp-B satellites, conducts nadir measurements around 9:30 am local time with footprints of

$1540 \times 80 \mathrm{~km}^{2}$ (or, since 2013, 40×40 km² for GOME-2A). By contrast, OMI, onboard the NASA's Earth Observing System Aura satellite, has 1:30 pm local overpass time with $13 \times 24 \mathrm{~km}^{2}$ pixel resolution. Data were downloaded from the European Space Agency's (ESA) Tropospheric Emission Monitoring Internet Service (TEMIS; http://www.temis.nl/airpollution/no2.html). TM4NO2A version 2.3 data were used for GOME-2, and DOMINO version 2.0 data were used for OMI. We disregarded contaminated data pixels or those with cloud fractions over $40 \%$ using quality

20 flags. The Differential Optical Absorption Spectroscopy (DOAS) technique was used for both products. Details regarding the $\mathrm{NO}_{2}$ column-retrieval algorithms and error analysis were described in Boersma et al. (2004, 2007). Pixels are converted to CMAQ domain grids using a conservative re-gridding method (Kim et al., 2016b).

The use of $\mathrm{NO}_{2} \mathrm{VCD}$ data is noteworthy. One might question why we used $\mathrm{NO}_{2} \mathrm{VCD}$ for the pollutant transport study, since $\mathrm{NO}_{2}$ is rarely used in chemical-transport studies because of a very short lifetime. This short life time, however, allows us to interpret $\mathrm{NO}_{2} \mathrm{VCD}$ as fresh anthropogenic emissions.

\subsection{Chemical transport model}

To estimate the generation and transport of pollutants, a chemistry transport model is integrated. Specifically, gas and aerosol concentrations over East Asia are simulated by using a Weather Research and Forecasting Model (WRF)-Sparse Matrix Operator Kernel Emission (SMOKE)-Community Multiscale Air Quality (CMAQ) modeling system. We used WRF

30 version 3.3.1 (Skamarock and Klemp, 2008) for the meteorology simulation, initiated with the NCEP GFS $0.5^{\circ} \times 0.5^{\circ}$ global product over a 27-km East Asia domain. Terrain and surface land types are taken from 90-m Shuttle Radar Topography Mission (SRTM) Digital Elevation Model (DEM) and Korean Ministry of Environment Land Use/Land Cover data. 
Atmos. Chem. Phys. Discuss., doi:10.5194/acp-2016-673, 2016

Atmospheric

Manuscript under review for journal Atmos. Chem. Phys.

Chemistry

Published: 9 September 2016

(c) Author(s) 2016. CC-BY 3.0 License.

$\frac{\text { and Physics }}{\text { Discussions }}$

(c) (i)

Chemical transport simulations are performed with CMAQ version 4.7.1 (Byun and Schere, 2006) with the AERO5 aerosol module and Statewide Air Pollution Research Center version 99 (SAPRC99; Carter, 1999). See Table 1 for the summary of the model configuration. As a preprocessor for the CMAQ simulation, the Meteorology-Chemistry Interface Processor (MCIP) version 3.6 is used. The 2006 Intercontinental Chemical Transport Experiment-Phase B (INTEX-B 2006) emissions

5 inventory (Zhang et al., 2009) was used, except inside South Korea, where we instead used the Clean Air Policy Support System (CAPSS) 2007 emissions inventory (Lee et al., 2011). The Model of Emissions of Gases and Aerosols from Nature (MEGAN; Guenther et al., 2006) was used to prepare biogenic emissions. Detailed descriptions on the model configurations and model performance evaluations are available at Kim et al., (2016a).

\section{Observed and modeled pollutants transport patterns in East Asia}

\section{$10 \quad 4.1 \quad$ Type 1: Expansion of the Siberian High}

Type 1 pattern is characterized by a prevailing high-pressure system in southern China (Fig. 2a) which affects both the development of local air pollutions and their subsequent transport. As a high-pressure system locates over southern China or the Yellow Sea, it provides an anticyclonic outflow that causes strong eastward transport of pollutants from the Chinese east coast (e.g., Shanghai) or northern China (e.g., Beijing) to Korea and Japan. This pattern is often accompanied by weak low-

15 pressure systems in the Manchuria. A cyclonic flow in the southern part of a low-pressure system can reinforce eastward transport of air pollutants.

When the high-pressure system remains attached to the Siberian High, its long-range transport pattern is more southeastward to eastward, passing through Mongolia as a possible pathway of wintertime Asian Dust transport to Korea (Kim and Park, 2001; Kim et al., 2001). Note that Type 1 is compatible with Cluster 2 in Kim et al. (2005) and the long-range transport type

20 in Lee et al. (2011). Figure 3 shows satellite images and modeled pollutants for a case study of Type 1. A prominent highpressure system over southern China and a weak low-pressure system in northern China cause a strong eastward pollutant transport from China to Korea during December 30-31, 2013. As the high-pressure system is expanded from the Siberian High, the northwesterlies from Mongolia to the Chinese east coast become dominant, resulting in strong outflow from the continent. These flow patterns are well represented in the CMAQ $\mathrm{PM}_{10}$ simulations as evident from the enhanced $\mathrm{PM}_{10}$

25 concentrations over the Yellow and East China Seas. MODIS AOD shows a similar spatial distribution to CMAQ PM 10 concentrations. GOME-2 and $\mathrm{OMI} \mathrm{NO} \mathrm{N}_{2}$ column density further show a good agreement over the east coast and the Yellow Sea, although they disagree in the southern part of the region. During this period, Korea experienced high surface $\mathrm{PM}_{10}$ concentrations, with a report of an Asian Dust (see Fig. 9 as discussed later). As such, the December 30-31, 2013 high $\mathrm{PM}_{10}$ concentration episode in Korea is likely caused by the combined impact of Chinese anthropogenic emissions and Asian Dust 30 transport.

Figure 4 depicts another example of Type 1 pollutant transport pattern. In this case, an expanded high-pressure system is detached from the Siberian High, showing more anticyclonic flow patterns over the Yellow Sea. Again, satellite-observed 
Atmos. Chem. Phys. Discuss., doi:10.5194/acp-2016-673, 2016

Atmospheric

Chemistry

Manuscript under review for journal Atmos. Chem. Phys.

Published: 9 September 2016

(c) Author(s) 2016. CC-BY 3.0 License.

and Physics

Discussions

(c) (i)

$\mathrm{NO}_{2}$ column densities, especially those from GOME-2, show an excellent agreement with the simulated distribution of surface $\mathrm{PM}_{10}$ concentrations, suggesting that anthropogenic emissions have likely contributed to high $\mathrm{PM}_{10}$ concentrations. Animation of this figure is available in the supplementary materials.

\subsection{Type 2: Cold frontal passage}

5 We separated Type 2 from Type 1 because Type 2 involves two sequential stages: i.e., (1) a prominent high-pressure system over southern China and (2) the growth of a dominant low-pressure system over northern China (Fig. 2b). Type 2 also differs from Type 1 in terms of pollutant transport direction. While Type 1 shows dominant westerly (and northwesterly inland from the Siberian High), Type 2 is mostly associated with northerly (and slightly northwesterly), related to the cold frontal passage of the low-pressure system. It is also highlighted by a radially shaped (or narrow-banded) pollutant transport that is

10 pushed by the passing cold front. Another important aspect of Type 2 pattern is its lifting capability, which is also associated with strong frontal activity.

Figure 5 shows the typical development of Type 2 synoptic weather pattern and pollutants during November 4-7, 2013. On November 4, a dominant high-pressure system over inland China provided a favorable condition for the consolidation of pollutants. There is also pollutant signal near or north of Beijing. On November 5, the high-pressure system was still strong,

15 but its center was displaced to the Yellow Sea. With help from the low-pressure system around Mongolia, the flow pattern across Beijing becomes southwesterly, pushing pollutants near Beijing northwestward and forming a heavily polluted air band up to Harbin or to Russian territory. On the next day, the low-pressure system strengthened, beginning to push condensed pollutants southward through the northerly winds associated with the cold front. Lastly, on November 7, the lowpressure system travelled eastward, and northerly winds behind the cold front pushed pollutants from the Manchurian region down to the southern boundary of Korea, resulting in a long and narrow band of pollutants from Shanghai to the Korean strait, and to the northern Hokkaido, Japan. This narrow, radial band (marked with a red arrow in rightmost column of Figure 5) is clearly shown in the GOME-2 $\mathrm{NO}_{2}$ column, MODIS AOD, and CMAQ surface $\mathrm{PM}_{10}$ concentrations. Regional atmospheric circulation patterns forming this narrow band of pollutants can be more clearly seen in the hourly model output; an animation of this is available in the supplementary materials.

25 Figure 6 shows another example of Type 2 narrow-band pollutants transport pattern from near Shanghai to Japan (marked with a red arrow), observed on April 5, 2014. The same band pattern can be seen from MODIS and VIIRS true color images in Figure 7. The white band and brownish plume offshore Shanghai might be a mixture of cloud and anthropogenic pollutants. This collocation may indicate the interaction of clouds and aerosols - enhancement of cloud with aerosol as cloud condensation nuclei and/or formation of secondary PM associated with cloud - in the region (Saide et al., 2015; B. Zhang et

30 al., 2015). Figure 6 exhibits another pollutant band over the open ocean along the cold front of the developed cyclone around northern Hokkaido (see Figure 7 for the location of the cold front). This band is clearly observed from MODIS AOD and CMAQ surface $\mathrm{PM}_{10}$ concentrations. Indeed, these two bands well represent an example of primary and secondary cold front passages (Bjerknes and Solberg, 1922). Although not shown, multi-year inspection of satellite observations and model 
Atmos. Chem. Phys. Discuss., doi:10.5194/acp-2016-673, 2016

Manuscript under review for journal Atmos. Chem. Phys.

simulations revealed that such a narrow band of pollutants is quite common in East Asia. In fact, a narrow-band plume over the open ocean also appears in Figure 4. The occurrences of Type 2 pollutant transport pattern are further shown in Figure 9 and discussed in Section 4.4.

\subsection{Type 3: Stagnant high-pressure system}

5 When a high-pressure system is stationary or moving slowly over southern China or Yellow Sea, there is a high chance of a multi-day high $\mathrm{PM}_{10}$ concentration episode (Fig. 2c). We have classified such cases as Type 3 . Figure 8 shows sequential plots of synoptic weather patterns and MODIS AOD from February 19-27, 2014, one of the worst high PM 10 concentration episodes in China and Korea. An anticyclonic system centered around the South China Sea (marked with a red arrow) became stagnant for almost a week. On February 19, the MODIS AOD was already very high over northern China, as this

10 region had already experienced a high $\mathrm{PM}_{10}$ concentration episode in the previous week, while AOD over Korea was relatively low. On February 22, the high AOD extended to the Yellow Sea and the west coast of Korea, remaining high until February 26 when the stagnant high-pressure system was pushed out by the newly developing low-pressure system over Manchuria. On February 27, the low-pressure system over Manchuria prevailed, and the high-pressure system over the Yellow Sea moved to the western Pacific. Then, the AOD and surface PM concentrations over China and Korea began to

15 decline.

Several previous studies have examined the pollutant episodes that occur under this type of stagnant condition, with a slowly-moving surface anticyclone. For instance, by investigating a high $\mathrm{PM}_{10}$ concentration episode in October 2008, Lee et al. (2013a) reported that the stagnant high-pressure system over Korea may play a decisive role in the accumulation of air pollutant in Seoul, Korea. Oh et al., (2015) also showed a strong positive geopotential height anomaly over Korea and Japan 20 during multi-day high $\mathrm{PM}_{10}$ concentration episodes during 2001-2013. Ji et al. (2014) analyzed PM composition measurements from 20 monitoring sites in northern China and documented a high sulfur and nitrogen oxidation ratio, suggesting additional production of sulfates and nitrates with high emissions, under stagnant weather conditions. They proposed that the formation of secondary PM is one important mechanism in the formation of heavy air pollution episodes. Zhang et al. (2014) also reported that inorganic species and secondary organic aerosol components contribute to high air

25 pollution episodes, most likely due to aqueous-phase processing under stagnant conditions with warm and humid air mass.

We also note that the dissipation of high $\mathrm{PM}_{10}$ concentration events under Type 3 pattern is mechanically similar to the second step of Type 2 transport pattern. The development of a low-pressure system over Manchuria and the passage of a cold front function as a very efficient mechanism to remove high levels of air pollutants from China and Korea. The role of the Manchurian low-pressure system as a sweeping mechanism of pollutants warrants further investigation.

\section{$30 \quad 4.4 \quad \mathbf{P M}_{10}$ time series in the Seoul Metropolitan Area (SMA), Korea}

Figure 9 shows timeseries of $\mathrm{PM}_{10}$ concentrations and meteorological conditions in the SMA during the two cool seasons, November 2012 to May 2013 and November 2013 to May 2014. In each upper panel, the shaded areas represent minimum 
Atmos. Chem. Phys. Discuss., doi:10.5194/acp-2016-673, 2016

Manuscript under review for journal Atmos. Chem. Phys.

and maximum $\mathrm{PM}_{10}$ concentrations from 105 surface monitoring sites in the SMA, with black dots representing all-site averages. Changes in surface pressure and wind speed are shown as red and blue dots, respectively, in the lower panels. The red asterisk (*) symbol indicates days of Asian Dust guidance as reported by the KMA (http://www.kma.go.kr/weather/asiandust/observday.jsp).

5 For each high $\mathrm{PM}_{10}$ concentration episode, related pollutant transport pattern type, according to our classification (e.g., Types 1-3), is identified (Figure 9). This classification is subjectively conducted by examining individual sub-daily surface weather maps and satellite observations. While each type does not always occur alone, Figure 9 provides a good evidence to support the hypothesis that SMA PM concentrations are highly associated with meteorological conditions in East Asia. Note that transport pattern is not designated if there is no prevailing weather pattern. Below, several key observations from Figure

109 are briefly described.

In general, we notice a prominent correlation between sea level pressure and wind speed changes. In many cases, when sea level pressure rapidly decreases, we observe increased wind speed, which seems to be a typical signal of the passage of frontal zone associated with traveling low-pressure systems (i.e., systems initiated from Altai-Sayan cyclogenesis region). Such signals happen frequently across the entire cool season; see November 7, 11, 18, 25, and 27 and December 9, 11, 20,

15 and 27, 2013, as examples.

The signal of frontal passage is a good indicator of Type 2 and Type 3 pollutant transport patterns. Usually, PM concentrations are accumulated under high-pressure systems. Later, the frontal passage (i.e., sea level pressure drops and wind speed increases) tends to dissipate the Type 2 high PM concentration events. When this cleaning mechanism is weak or does not happen for multiple days (i.e., when the frontal passage associated with migratory low-pressure systems does not

20 sweep out the PM concentrations), we could observe a Type 3 pattern with a stagnant high-pressure system. Note that Type 1 pattern differs from Type 2 or Type 3 , in terms of an early increase of wind speed during high $\mathrm{PM}_{10}$ concentration events. In many cases, the Type 1 pattern pushes pollutants from northern China to Korea and Japan. This pattern is also associated with the long-range transport of Asian Dust.

The synoptic weather pattern, associated with pollutant transport, is often very complicated, making it very challenging to clearly separate one from another. In many cases, high PM concentration events in the SMA are caused by combinations of multiple synoptic weather patterns. However, one general observation can be summarized as follows. For persistent high PM concentration events, the existence of a prevailing high-pressure system is essential. On the other hand, a low-pressure system, which accompanies strong cold-frontal activity, functions not only as a strong transporting force, especially in the case of Asian Dust, but also as a cleaning mechanism for Type 2 and Type 3 patterns.

\section{$\begin{array}{lll}30 & 5 & \text { Summary and Conclusions }\end{array}$}

The present study examines pollutant transport patterns in East Asia and attempts to visualize them using all available satellite images and chemistry transport model output. It is shown that the spatial distribution of satellite-observed AOD, 
Atmos. Chem. Phys. Discuss., doi:10.5194/acp-2016-673, 2016

Manuscript under review for journal Atmos. Chem. Phys.

$\mathrm{NO}_{2}$ column densities, and modeled PM concentrations are well associated with the synoptic weather charts on daily or hourly timescales. This result allows us to directly relate the development and transport of regional air pollutants with synoptic weather patterns.

During the cool season (fall to spring), a periodic expansion of the Siberian High plays a crucial role in the development and

5 transport of pollutants and their precursors. Based on the relative location and strength of high-pressure systems over southern China and low-pressure systems over Manchuria, we subjectively classified three representative synoptic weather patterns that affect high surface-PM concentration events in China and Korea. They are (1) a periodic southeastward expansion of the Siberian High, (2) a cold-frontal passage associated with a travelling low-pressure system in northern China, and (3) a stagnant high-pressure system over southern China. In all cases, the development of a high-pressure system in southern China is essential, providing favorable meteorological condition for the long range transport of pollutants.

Key findings, along with the suggestions for the future studies, are summarized as below.

1. The impact of synoptic weather systems on regional air quality is quite systematic in East Asia. Both high-pressure and low-pressure systems play an important role in the development and transport of pollutants. While the former provides meteorological condition that is favorable for the development of high levels of air pollution (i.e., a clear and calm sky with subsidence), the latter tends to force long-range transport of pollutants. More importantly, these two weather systems often come together; a high-pressure system loads pollutants then low-pressure systems push them off the continent or out to the Pacific Ocean. During the cool season, there are routine passages of travelling high- and low-pressure systems, implying that increasing anthropogenic emissions from China, especially from Northeastern China, can significantly affect air quality in neighboring countries.

2. Low-pressure systems over Manchuria, initiated by Altai-Sayan cyclogenesis, play a complicated role. While such systems often initiate and deliver Asian dust, they also work as a cleaning and scavenging mechanism of pollutants. A low-pressure system is also able to effectively lift pollutants through their associated cold-frontal activities and transport them eastward.

3. Even without changes in anthropogenic emissions from China, changes in meteorological conditions that control the stagnant weather condition may affect regional air quality. With an increasing and continuous trend of anthropogenic emissions from China, the general transport pattern works to magnify the impact of these emissions on neighboring countries air quality. But, more intensive analysis should be undertaken to better understand or resolve this problem.

4. Notably, a quantitative estimate of the contributions from Chinese pollutants to Korean pollution events is still unclear. Though satellite images show a slow but clear propagation of high AOD plumes from northern China to the Yellow Sea in some cases, it would be premature to conclude that Chinese pollutant transport to Korea makes a dominant contribution to such episodes. The whole region around the Yellow Sea is under very similar meteorological conditions during a stagnant surface anticyclone, so it is not easy to separate regional transport from local development without a help of a proper chemistry transport modeling. A more quantitative interpretation of 
Atmos. Chem. Phys. Discuss., doi:10.5194/acp-2016-673, 2016

Manuscript under review for journal Atmos. Chem. Phys.

this system, using model simulations based on process analyses, will be discussed in a forthcoming study (Kim et al., in preparation).

\section{Appendix:}

\subsection{GIS geo-referencing method}

5 To closely investigate the relationship between synoptic weather pattern and satellite or model data, we used a georeferencing technique, a GIS technique that associates plain images, such as satellite- or plane-taken photos with a map coordinate.

In this study, KMA surface weather charts are combined with satellite images. To do so, we developed an automatic georeferencing tool using Interactive Data Language (IDL) routines from the National Oceanic and Atmospheric

10 Administration Air Resources Laboratory's IDL-based Geospatial Data Processor library (IGDP, Kim et al., 2013). This tool obtains surface weather charts (PNG files from the KMA website), builds geographical information for each pixel of the PNG, and plots this information on top of satellite data or model output. Although this georeferencing method is also available in several GIS software packages, a fully automatized processing routine was required to analysis massive amounts (i.e., three-hourly views for two years) of data.

15 This technique is similar to image morphing or texture warping in computer graphics. The IDL POLYWARP procedure performs polynomial spatial warping. Using least squares estimation, POLYWARP determines the coefficients $K x_{\mathrm{i}, \mathrm{j}}$ and $K y_{\mathrm{i}, \mathrm{j}}$ of the polynomial functions:

$$
\begin{aligned}
X_{i} & =\sum_{i, j} K_{X_{i, j}} \cdot X_{o}^{j} \cdot Y_{o}^{i} \\
Y_{i} & =\sum_{i, j} K_{Y_{i, j}} \cdot X_{o}^{j} \cdot Y_{o}^{i}
\end{aligned}
$$

This coordinate transformation may then be used to map $X_{o}, Y_{o}$ coordinates to $X_{i}, Y_{i}$ coordinates. We determine the transforming matrices $\mathrm{K}_{\mathrm{x}}$ and $\mathrm{K}_{\mathrm{y}}$ using the manual method, linking several locations from the original weather chart and the target domain map (see Figure 10b).

When these matrices are applied, the original image can be deformed to the target domain. This conversion is also reversible. For faster data processing, we applied the inverse of the transforming matrices to the longitude and latitude of the target domain, thereby constructing the longitude and latitude at each pixel of the original KMA weather chart. Processing procedures are summarized as follows.

(1) Read GIF (Figure 10a).

(2) Manually link deformation (Figure 10b).

(3) Assign longitude and latitude to each pixel in the target graphic (Figure 10c).

(4) Perform backwards deformation (Target to Original). 
Atmos. Chem. Phys. Discuss., doi:10.5194/acp-2016-673, 2016

Manuscript under review for journal Atmos. Chem. Phys.

Published: 9 September 2016

(c) Author(s) 2016. CC-BY 3.0 License.

(c) (i)

Atmospheric

Chemistry

and Physics

Discussions

(5) Save deformed longitude or latitude.

(6) Extract colors from GIF (Blue \& Red).

(7) Plot over target graphic (Figure 10d).

Using this method, we can estimate longitude and latitude information for each pixel of the original image. This information

5 is saved and reused for any additional graphics. Note that steps 2-5 are executed just once. The deformation calculation is quite accurate except at boundary regions. Sample IDL code for georeferencing is included in the supplementary materials.

\section{Acknowledgement}

This research was partly supported by National Institute of Environmental Research, Korea Ministry of Environment (as 'Climate Change Correspondence Program'), and NOAA Air Resources Laboratory.

\section{References}

Behera, S. N. and Sharma, M.: Investigating the potential role of ammonia in ion chemistry of fine particulate matter formation for an urban environment., The Science of the total environment, 408(17), 3569-75, doi:10.1016/j.scitotenv.2010.04.017, 2010.

Boersma, K. F., Eskes, H. J. and Brinksma, E. J.: Error analysis for tropospheric NO 2 retrieval from space, Journal of 15 Geophysical Research, 109(D4), D04311, doi:10.1029/2003JD003962, 2004.

Boersma, K. F., Eskes, H. J., Veefkind, J. P., Brinksma, E. J., van der A, R. J., Sneep, M., van den Oord, G. H. J., Levelt, P. F., Stammes, P., Gleason, J. F. and Bucsela, E. J.: Near-real time retrieval of tropospheric NO2 from OMI, Atmospheric Chemistry and Physics, 7(8), 2103-2118, doi:10.5194/acp-7-2103-2007, 2007.

Byun, D. and Schere, K. L.: Review of the Governing Equations, Computational Algorithms, and Other Components of the

20 Models-3 Community Multiscale Air Quality (CMAQ) Modeling System, Applied Mechanics Reviews, 59(2), 51, doi:10.1115/1.2128636, 2006.

Carter, W. P. L.: Documentation of the SAPRC-99 Chemical Mechanism for VOC Reactivity Assessment, Assessment, 1, 329 [online] Available from: http://www.engr.ucr.edu.oca.ucsc.edu/ carter/pubs/s99doc.pdf, 1999.

Chen, S.-J., Kuo, Y.-H., Zhang, P.-Z. and Bai, Q.-F.: Synoptic Climatology of Cyclogenesis over East Asia, 1958-1987, Monthly Weather Review, 119(6), 1407-1418, doi:10.1175/1520-0493(1991)119<1407:SCOCOE>2.0.CO;2, 1991.

Chen, Z. H., Cheng, S. Y., Li, J. B., Guo, X. R., Wang, W. H. and Chen, D. S.: Relationship between atmospheric pollution processes and synoptic pressure patterns in northern China, Atmospheric Environment, 42(24), 6078-6087, doi:10.1016/j.atmosenv.2008.03.043, 2008.

Cheng, C. S., Campbell, M., Li, Q., Li, G., Auld, H., Day, N., Pengelly, D., Gingrich, S. and Yap, D.: A synoptic

30 climatological approach to assess climatic impact on air quality in south-central Canada. Part I: Historical analysis, Water, Air, and Soil Pollution, 182(1-4), 131-148, 2007. 
Atmos. Chem. Phys. Discuss., doi:10.5194/acp-2016-673, 2016

Manuscript under review for journal Atmos. Chem. Phys.

Published: 9 September 2016

(c) Author(s) 2016. CC-BY 3.0 License.

Chun, Y., Boo, K.-O., Kim, J., Park, S.-U. and Lee, M.: Synopsis, transport, and physical characteristics of Asian dust in Korea, Journal of Geophysical Research, 106(D16), 18461, 2001.

Chung, Y.-S.: On the observations of yellow sand (dust storms) in Korea, Atmospheric Environment. Part A. General Topics, 26(15), 2743-2749, doi:10.1016/0960-1686(92)90010-I, 1992.

5 Cohen, J., Saito, K. and Entekhabi, D.: The role of the Siberian high in northern hemisphere climate variability, Geophysical Research Letters, 28(2), 299-302, doi:10.1029/2000GL011927, 2001.

Compo, G. P., Kiladis, G. N. and Webster, P. J.: The horizontal and vertical structure of east Asian winter monsoon pressure surges, Quarterly Journal of the Royal Meteorological Society, 125(553), 29-54, doi:10.1256/smsqj.55302, 1999.

Dickerson, R. R., Li, C., Li, Z., Marufu, L. T., Stehr, J. W., McClure, B., Krotkov, N., Chen, H., Wang, P., Xia, X., Ban, X.,

10 Gong, F., Yuan, J. and Yang, J.: Aircraft observations of dust and pollutants over northeast China: Insight into the meteorological mechanisms of transport, Journal of Geophysical Research, 112(D24), D24S90, doi:10.1029/2007JD008999, 2007.

Ding, A., Wang, T., Xue, L., Gao, J., Stohl, A., Lei, H., Jin, D., Ren, Y., Wang, X., Wei, X., Qi, Y., Liu, J. and Zhang, X.: Transport of north China air pollution by midlatitude cyclones: Case study of aircraft measurements in summer 2007,

15 Journal of Geophysical Research, 114(D8), D08304, doi:10.1029/2008JD011023, 2009.

Ding, K., Liu, J., Ding, A., Liu, Q., Zhao, T. L., Shi, J., Han, Y., Wang, H. and Jiang, F.: Uplifting of carbon monoxide from biomass burning and anthropogenic sources to the free troposphere in East Asia, Atmospheric Chemistry and Physics, 15(5), 2843-2866, doi:10.5194/acp-15-2843-2015, 2015.

Frioud, M., Mitev, V., Matthey, R., Häberli, C. H., Richner, H., Werner, R. and Vogt, S.: Elevated aerosol stratification

20 above the Rhine Valley under strong anticyclonic conditions, Atmospheric Environment, 37, 1785-1797, doi:10.1016/S1352-2310(03)00049-9, 2003.

Garreaud, R. D.: Subtropical cold surges: regional aspects and global distribution, International Journal of Climatology, 21(10), 1181-1197, doi:10.1002/joc.687, 2001.

Gong, D.-Y. and Ho, C.-H.: The Siberian High and climate change over middle to high latitude Asia, Theoretical and Applied Climatology, 72(1-2), 1-9, doi:10.1007/s007040200008, 2002.

Guan, D., Peters, G. P., Weber, C. L. and Hubacek, K.: Journey to world top emitter: An analysis of the driving forces of China's recent CO 2 emissions surge, Geophysical Research Letters, 36(4), L04709, doi:10.1029/2008GL036540, 2009.

Guenther, A., Karl, T., Harley, P., Wiedinmyer, C., Palmer, P. I. and Geron, C.: Estimates of global terrestrial isoprene emissions using MEGAN (Model of Emissions of Gases and Aerosols from Nature), Atmospheric Chemistry and Physics, 6(11), 3181-3210, doi:10.5194/acp-6-3181-2006, 2006.

HENRY, A. J.: J. BJERKNES AND H. SOLBERG ON THE LIFE CYCLE OF CYCLONES AND THE POLAR FRONT THEORY OF ATMOSPHERIC CIRCULATION 1, Monthly Weather Review, 50(9), 468-473, doi:10.1175/15200493(1922)50<468:JBAHSO>2.0.CO;2, 1922.

Husar, R. B., Tratt, D. M., Schichtel, B. a., Falke, S. R., Li, F., Jaffe, D., Gassó, S., Gill, T., Laulainen, N. S., Lu, F., Reheis,

M. C., Chun, Y., Westphal, D., Holben, B. N., Gueymard, C., McKendry, I., Kuring, N., Feldman, G. C., McClain, C., 
Atmos. Chem. Phys. Discuss., doi:10.5194/acp-2016-673, 2016

Manuscript under review for journal Atmos. Chem. Phys.

Published: 9 September 2016

(c) Author(s) 2016. CC-BY 3.0 License.

Frouin, R. J., Merrill, J., DuBois, D., Vignola, F., Murayama, T., Nickovic, S., Wilson, W. E., Sassen, K., Sugimoto, N. and Malm, W. C.: Asian dust events of April 1998, Journal of Geophysical Research, 106(D16), 18317, doi:10.1029/2000JD900788, 2001.

Im, U., Tayanç, M. and Yenigün, O.: Interaction patterns of major photochemical pollutants in Istanbul, Turkey,

Atmospheric Research, 89, 382-390, doi:10.1016/j.atmosres.2008.03.015, 2008.

Iwasaka, Y., Minoura, H. and Nagaya, K.: The transport and spacial scale of Asian dust-storm clouds: a case study of the dust-storm event of April 1979, Tellus B, 35(3), 189-196, 1983.

Jeong, U., Kim, J., Lee, H., Jung, J., Kim, Y. J., Song, C. H. and Koo, J.-H.: Estimation of the contributions of long range transported aerosol in East Asia to carbonaceous aerosol and PM concentrations in Seoul, Korea using highly time resolved

10 measurements: a PSCF model approach., Journal of environmental monitoring : JEM, 13(7), 1905-18, doi:10.1039/c0em00659a, 2011.

Ji, D., Li, L., Wang, Y., Zhang, J., Cheng, M., Sun, Y., Liu, Z., Wang, L., Tang, G., Hu, B., Chao, N., Wen, T. and Miao, H.: The heaviest particulate air-pollution episodes occurred in northern China in January, 2013: Insights gained from observation, Atmospheric Environment, 92, 546-556, doi:10.1016/j.atmosenv.2014.04.048, 2014.

15 Kim, B.: Transport and evolution of a winter-time Yellow sand observed in Korea, Atmospheric Environment, 35(18), 3191-3201, doi:10.1016/S1352-2310(00)00469-6, 2001.

Kim, B.-G., Han, J.-S. and Park, S.-U.: Transport of SO2 and aerosol over the Yellow sea, Atmospheric Environment, 35(4), 727-737, doi:10.1016/S1352-2310(00)00344-7, 2001.

Kim, B.-U., Kim, O., Kim, H. C. and Kim, S.: Influence of Fossil-Fuel Power Plant Emissions on the Surface PM2.5 in the

20 Seoul Capital Area, South Korea., Journal of the Air \& Waste Management Association (1995), doi:10.1080/10962247.2016.1175392, 2016a.

Kim, H. C., Lee, P., Judd, L., Pan, L. and Lefer, B.: OMI NO 2 column densities over North American urban cities: the effect of satellite footprint resolution, Geoscientific Model Development, 9(3), 1111-1123, doi:10.5194/gmd-9-1111-2016, $2016 \mathrm{~b}$.

Kim, H., Ngan, F., Lee, P. and Tong, D.: Development of IDL-based geospatial data processing framework for meteorology

25 and air quality modeling. [online] Available from: http://aqrp.ceer.utexas.edu/projectinfoFY12_13\%5C12-TN2\%5C12-TN2 Final Report.pdf, 2013.

Kim, J.: Transport routes and source regions of Asian dust observed in Korea during the past 40 years (1965-2004), Atmospheric Environment, 42(19), 4778-4789, doi:10.1016/j.atmosenv.2008.01.040, 2008.

Kim, J., Yoon, S.-C., Jefferson, A., Zahorowski, W. and Kang, C.-H.: Air mass characterization and source region analysis 30 for the Gosan super-site, Korea, during the ACE-Asia 2001 field campaign, Atmospheric Environment, 39(35), 6513-6523, doi:10.1016/j.atmosenv.2005.07.021, 2005.

Kim, Y., Kim, S.-W., Yoon, S.-C., Kim, M.-H. and Park, K.-H.: Aerosol properties and associated regional meteorology during winter pollution event at Gosan climate observatory, Korea, Atmospheric Environment, 85(X), 9-17, doi:10.1016/j.atmosenv.2013.11.041, 2014. 
Atmos. Chem. Phys. Discuss., doi:10.5194/acp-2016-673, 2016

Manuscript under review for journal Atmos. Chem. Phys.

Published: 9 September 2016

(c) Author(s) 2016. CC-BY 3.0 License.

Lee, C., Richter, A., Lee, H., Kim, Y. J., Burrows, J. P., Lee, Y. G. and Choi, B. C.: Impact of transport of sulfur dioxide from the Asian continent on the air quality over Korea during May 2005, Atmospheric Environment, 42(7), 1461-1475, doi:10.1016/j.atmosenv.2007.11.006, 2008.

Lee, D., Lee, Y., Jang, K., Yoo, C., Kang, K., Lee, J., Jung, S., Park, J., Lee, S., Han, J., Hong, J. and Lee, S.: Korean

5 National Emissions Inventory System and 2007 Air Pollutant Emissions, Asian Journal of Atmospheric Environment, 5(4), 278-291, 2011a.

Lee, H.-J., Kim, S.-W., Brioude, J., Cooper, O. R., Frost, G. J., Kim, C.-H., Park, R. J., Trainer, M. and Woo, J.-H.: Transport of NO $\mathrm{x}$ in East Asia identified by satellite and in situ measurements and Lagrangian particle dispersion model simulations, Journal of Geophysical Research: Atmospheres, 119(5), 2574-2596, doi:10.1002/2013JD021185, 2014.

10 Lee, S., Ho, C.-H. H. and Choi, Y.-S. S.: High-PM10 concentration episodes in Seoul, Korea: Background sources and related meteorological conditions, Atmospheric Environment, 45(39), 7240-7247, doi:10.1016/j.atmosenv.2011.08.071, $2011 b$.

Lee, S., Ho, C.-H. H., Lee, Y. G., Choi, H.-J. J. and Song, C.-K. K.: Influence of transboundary air pollutants from China on the high-PM10 episode in Seoul, Korea for the period October 16-20, 2008, Atmospheric Environment, 77, 430-439, doi:10.1016/j.atmosenv.2013.05.006, 2013.

Levy, R. C., Mattoo, S., Munchak, L. a., Remer, L. a., Sayer, a. M., Patadia, F. and Hsu, N. C.: The Collection 6 MODIS aerosol products over land and ocean, Atmospheric Measurement Techniques, 6(11), 2989-3034, doi:10.5194/amt-6-29892013, 2013.

Liu, H., Jadob, D., Bey, I., Yantosca, R. and Duncan, B.: Transport pathways for Asian pollution outflow over the Pacific: Interannual and seasonal variations, Journal of Geophysical Research, 108(D20), 8786, doi:10.1029/2002JD003102, 2003.

Merrill, J. T. and Kim, J.: Meteorological events and transport patterns in ACE-Asia, Journal of Geophysical Research, 109(D19), D19S18, doi:10.1029/2003JD004124, 2004.

Moreno, T., Kojima, T., Querol, X., Alastuey, A., Amato, F. and Gibbons, W.: Natural versus anthropogenic inhalable aerosol chemistry of transboundary East Asian atmospheric outflows into western Japan., The Science of the total environment, 424, 182-92, doi:10.1016/j.scitotenv.2012.02.060, 2012.

Oh, H.-R., Ho, C.-H., Kim, J., Chen, D., Lee, S., Choi, Y.-S., Chang, L.-S. and Song, C.-K.: Long-range transport of air pollutants originating in China: A possible major cause of multi-day high-PM10 episodes during cold season in Seoul, Korea, Atmospheric Environment, 109, 23-30, doi:10.1016/j.atmosenv.2015.03.005, 2015.

Ou-Yang, C.-F., Hsieh, H.-C., Wang, S.-H., Lin, N.-H., Lee, C.-T., Sheu, G.-R. and Wang, J.-L.: Influence of Asian 30 continental outflow on the regional background ozone level in northern South China Sea, Atmospheric Environment, 78, 144-153, doi:10.1016/j.atmosenv.2012.07.040, 2013.

Park, R. J. and Kim, S.-W.: Air quality modeling in East Asia: present issues and future directions, Asia-Pacific Journal of Atmospheric Sciences, 50(1), 105-120, doi:10.1007/s13143-014-0030-9, 2014.

Park, T.-W., Ho, C.-H. and Deng, Y.: A synoptic and dynamical characterization of wave-train and blocking cold surge over

East Asia, Climate Dynamics, 2005, doi:10.1007/s00382-013-1817-6, 2013. 
Atmos. Chem. Phys. Discuss., doi:10.5194/acp-2016-673, 2016

Manuscript under review for journal Atmos. Chem. Phys.

Published: 9 September 2016

(c) Author(s) 2016. CC-BY 3.0 License.

Richter, A., Burrows, J. P., Nüss, H., Granier, C. and Niemeier, U.: Increase in tropospheric nitrogen dioxide over China observed from space., Nature, 437(7055), 129-32, doi:10.1038/nature04092, 2005.

Saide, P. E., Spak, S. N., Pierce, R. B., Otkin, J. A., Schaack, T. K., Heidinger, A. K., da Silva, A. M., Kacenelenbogen, M., Redemann, J. and Carmichael, G. R.: Central American biomass burning smoke can increase tornado severity in the U.S.,

Geophysical Research Letters, 42(3), 956-965, doi:10.1002/2014GL062826, 2015.

Skamarock, W. C. and Klemp, J. B.: A time-split nonhydrostatic atmospheric model for weather research and forecasting applications, Journal of Computational Physics, 227(7), 3465-3485, doi:10.1016/j.jcp.2007.01.037, 2008.

Stein, a. F., Draxler, R. R., Rolph, G. D., Stunder, B. J. B., Cohen, M. D. and Ngan, F.: NOAA's HYSPLIT Atmospheric Transport and Dispersion Modeling System, Bulletin of the American Meteorological Society, 96(12), 2059-2077, doi:10.1175/BAMS-D-14-00110.1, 2015.

Sun, W.-Y., Yang, K. J.-S. and Lin, N.-H.: Numerical Simulations of Asian Dust-Aerosols and Regional Impact on Weather and Climate- Part II: PRCM-Dust Model Simulation, Aerosol and Air Quality Research, 8584, doi:10.4209/aaqr.2013.06.0208, 2013.

Tai, A. P. K., Mickley, L. J. and Jacob, D. J.: Correlations between fine particulate matter (PM2.5) and meteorological 15 variables in the United States: Implications for the sensitivity of PM2.5 to climate change, Atmospheric Environment, 44(32), 3976-3984, doi:10.1016/j.atmosenv.2010.06.060, 2010.

Tan, S., Shi, G. and Wang, H.: Long-range transport of spring dust storms in Inner Mongolia and impact on the China seas, Atmospheric Environment, 46, 299-308, doi:10.1016/j.atmosenv.2011.09.058, 2012.

UN: National reporting guidelines for CSD-14/15 Thematic areas - Atmosphere/Air Pollution, Republic of Korea. [online] Available from: http://www.un.org/esa/agenda21/natlinfo/countr/repkorea/atmosphere.pdf, 2006.

Verstraeten, W. W., Neu, J. L., Williams, J. E., Bowman, K. W., Worden, J. R. and Boersma, K. F.: Rapid increases in tropospheric ozone production and export from China, Nature Geoscience, 8(9), 690-695, doi:10.1038/ngeo2493, 2015.

Wang, Y., Wang, M., Zhang, R., Ghan, S. J., Lin, Y., Hu, J., Pan, B., Levy, M., Jiang, J. H. and Molina, M. J.: Assessing the effects of anthropogenic aerosols on Pacific storm track using a multiscale global climate model., Proceedings of the National Academy of Sciences of the United States of America, 1073, doi:10.1073/pnas.1403364111, 2014.

Wei, P., Cheng, S., Li, J. and Su, F.: Impact of boundary-layer anticyclonic weather system on regional air quality, Atmospheric Environment, 45(14), 2453-2463, doi:10.1016/j.atmosenv.2011.01.045, 2011.

World Health Organization, WHO Air quality guidelines for particulate matter, ozone, nitrogen dioxide and sulfur dioxide. [online] Available from: http://apps.who.int/iris/bitstream/10665/69477/1/WHO_SDE_PHE_OEH_06.02_eng.pdf, 2005. [

Last access on Sep. 6, 2016]

WMO: GAW Report No . 205 WMO / IGAC Impacts of Megacities on Air Pollution and Climate. [online] Available from: http://www.wmo.int/pages/prog/arep/gaw/documents/GAW_205_DRAFT_13_SEPT.pdf, 2012.

Wong, H. L. a., Wang, T., Ding, A., Blake, D. R. and Nam, J. C.: Impact of Asian continental outflow on the concentrations of O3, CO, NMHCs and halocarbons on Jeju Island, South Korea during March 2005, Atmospheric Environment, 41(14), 
Atmos. Chem. Phys. Discuss., doi:10.5194/acp-2016-673, 2016

Manuscript under review for journal Atmos. Chem. Phys.

Published: 9 September 2016

(c) Author(s) 2016. CC-BY 3.0 License.

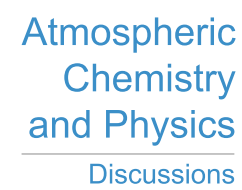

(c) (1)

Wu, B. and Wang, J.: Winter Arctic Oscillation, Siberian High and East Asian Winter Monsoon, Geophysical Research Letters, 29(19), 1897, doi:10.1029/2002GL015373, 2002.

Zhang, B., Wang, Y. and Hao, J.: Simulating aerosol-radiation-cloud feedbacks on meteorology and air quality over eastern China under severe haze conditionsin winter, Atmospheric Chemistry and Physics, 15(5), 2387-2404, doi:10.5194/acp-15-

$5 \quad 2387-2015,2015$.

Zhang, J. K., Sun, Y., Liu, Z. R., Ji, D. S., Hu, B., Liu, Q. and Wang, Y. S.: Characterization of submicron aerosols during a month of serious pollution in Beijing, 2013, Atmospheric Chemistry and Physics, 14(6), 2887-2903, doi:10.5194/acp-142887-2014, 2014.

Zhang, Q., Streets, D. G., Carmichael, G. R., He, K. B., Huo, H., Kannari, A., Klimont, Z., Park, I. S., Reddy, S., Fu, J. S., 10 Chen, D., Duan, L., Lei, Y., Wang, L. T. and Yao, Z. L.: Asian emissions in 2006 for the NASA INTEX-B mission, Atmospheric Chemistry and Physics, 9(14), 5131-5153, doi:10.5194/acp-9-5131-2009, 2009.

Zhang, Q., Streets, D. G., He, K., Wang, Y., Richter, A., Burrows, J. P., Uno, I., Jang, C. J., Chen, D., Yao, Z. and Lei, Y.: NO x emission trends for China, 1995-2004: The view from the ground and the view from space, Journal of Geophysical Research, 112(D22), D22306, doi:10.1029/2007JD008684, 2007.

15 Zhang, Y., Ding, A., Mao, H., Nie, W., Zhou, D., Liu, L., Huang, X. and Fu, C.: Impact of synoptic weather patterns and inter-decadal climate variability on air quality in the North China Plain during 1980-2013, Atmospheric Environment, 124, 119-128, doi:10.1016/j.atmosenv.2015.05.063, 2016. 
Atmos. Chem. Phys. Discuss., doi:10.5194/acp-2016-673, 2016

Manuscript under review for journal Atmos. Chem. Phys.

Published: 9 September 2016

(c) Author(s) 2016. CC-BY 3.0 License.

Table 1. CMAQ configuration used in this study.

Description

CMAQ

Chemical Mechanism

Chemical Solver

Aerosol Module

Boundary Condition

Advection Scheme

Horizontal Diffusion

Vertical Diffusion

Cloud Scheme
Version 4.7.1

SAPRC 99

EBI

AERO5

Default profile for the $27-\mathrm{km}$ domain

YAMO

Multiscale

Eddy

RADM 
Atmos. Chem. Phys. Discuss., doi:10.5194/acp-2016-673, 2016

Manuscript under review for journal Atmos. Chem. Phys.

Published: 9 September 2016

(c) Author(s) 2016. CC-BY 3.0 License.

\section{(c) (1)}

Atmospheric

Chemistry

and Physics

Discussions

\section{Terrain Height}

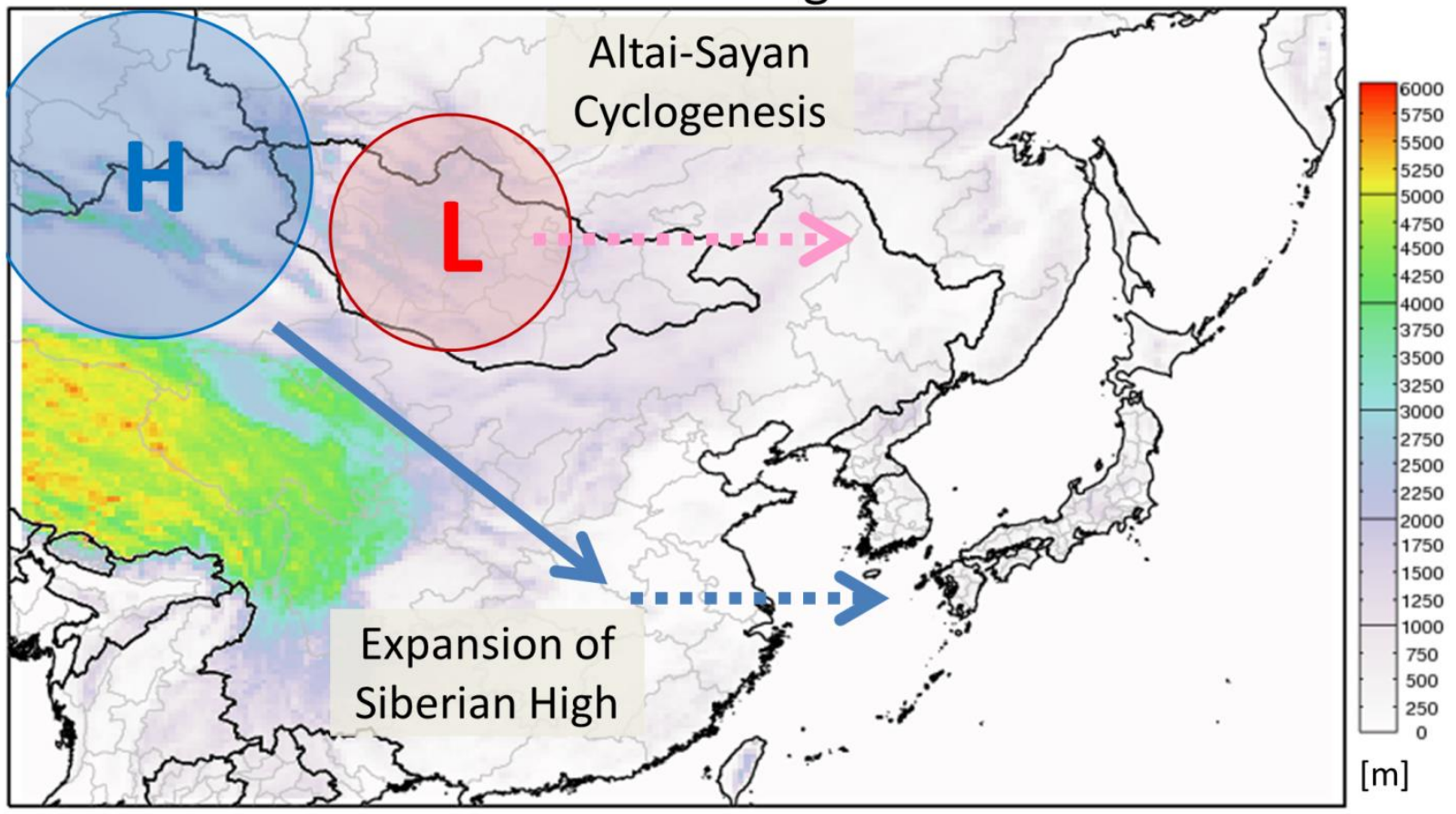

Figure 1 Major synoptic weather systems in East Asia during the cool season (autumn to spring). $\mathrm{H}$ and $\mathrm{L}$ denote the center of high and low pressure systems, respectively. Arrows indicate the travelling directions. 
Atmos. Chem. Phys. Discuss., doi:10.5194/acp-2016-673, 2016

Manuscript under review for journal Atmos. Chem. Phys.

Published: 9 September 2016

(c) Author(s) 2016. CC-BY 3.0 License.

(A)

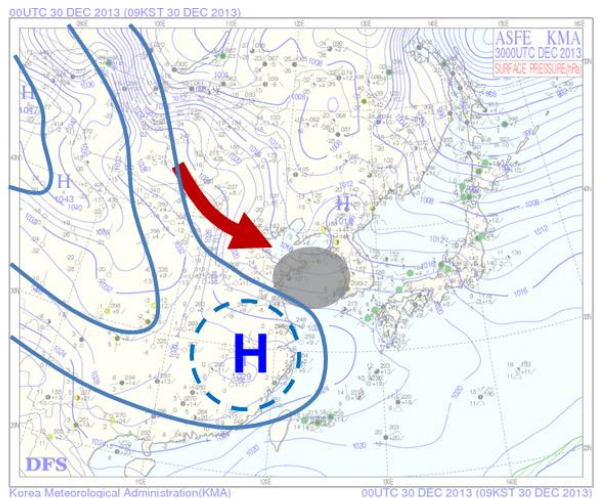

(B)
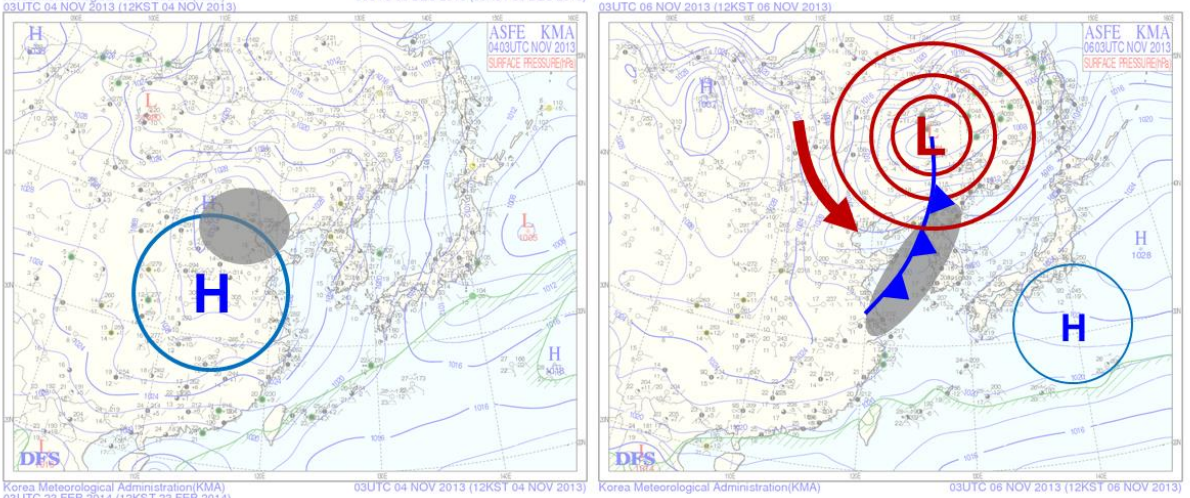

(C)

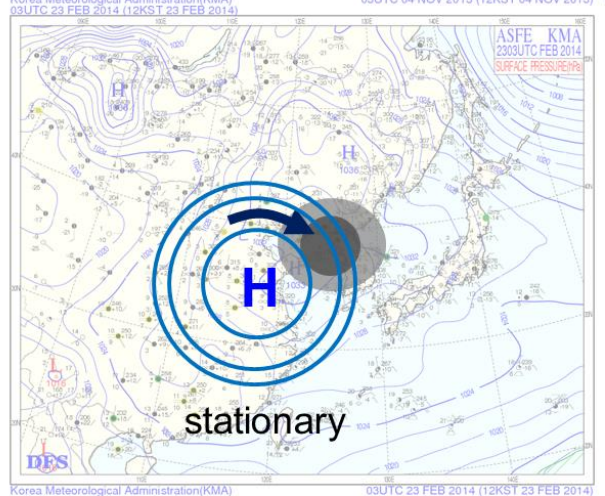

Figure 2 Three dominant synoptic weather patterns associated with pollutant transports in East Asia: (a) an southeastward expansion of high-pressure system from the Siberian high and a relatively weak low-pressure system in the North; (b) a highpressure system pushed by a growing low-pressure system; (c) a stagnant high-pressure system near the eastern Chinese coast or over the Yellow Sea. Gray-shaded areas indicate highly pollutant plumes. 
Atmos. Chem. Phys. Discuss., doi:10.5194/acp-2016-673, 2016

Manuscript under review for journal Atmos. Chem. Phys.

Published: 9 September 2016

(c) Author(s) 2016. CC-BY 3.0 License.
Atmospheric

Chemistry

and Physics

Discussions

(c) $\underset{\mathrm{Br}}{\mathrm{Br}}$
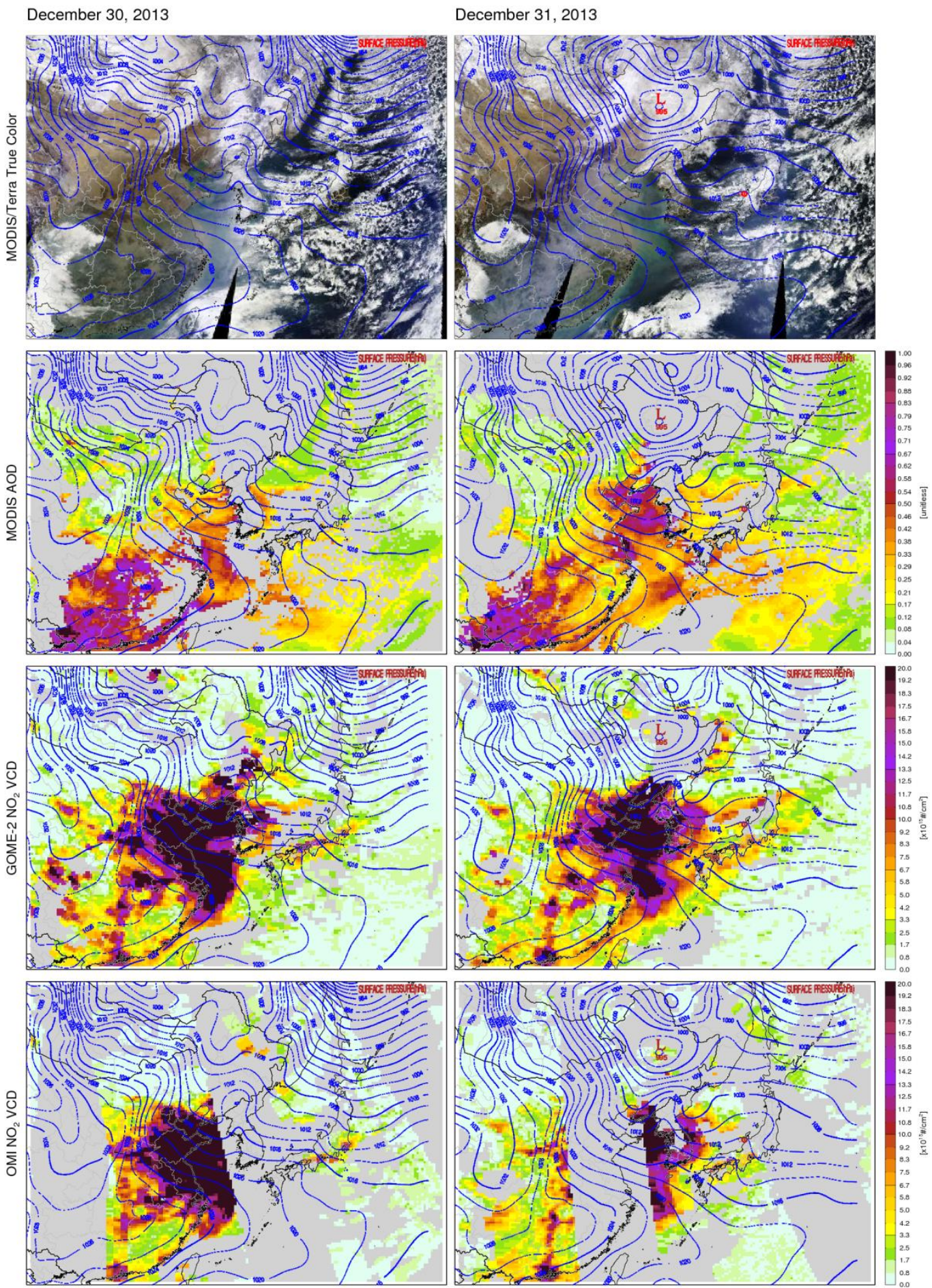

Figure 3 Case of southeastward expansion of the Siberian high (Type 1; Fig. 2a) from December 30-31, 2013 with MODIS True Color image, MODIS AOD, GOME-2 $\mathrm{NO}_{2}$ column density, OMI NO 2 column density, CMAQ simulated AOD, CMAQ simulated $\mathrm{NO}_{2}$ column density, and CMAQ simulated surface $\mathrm{PM}_{10}$ shown. 
Atmos. Chem. Phys. Discuss., doi:10.5194/acp-2016-673, 2016

Manuscript under review for journal Atmos. Chem. Phys.

Published: 9 September 2016

(c) Author(s) 2016. CC-BY 3.0 License.
Atmospheric

Chemistry

and Physics

Discussions

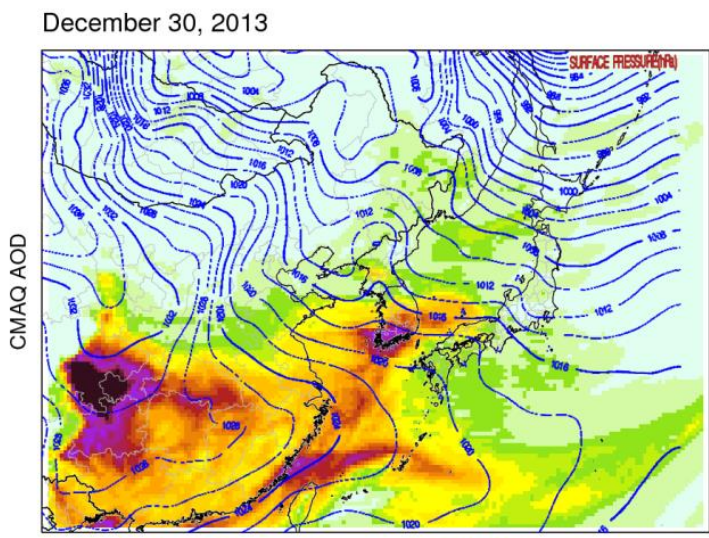

December 31, 2013
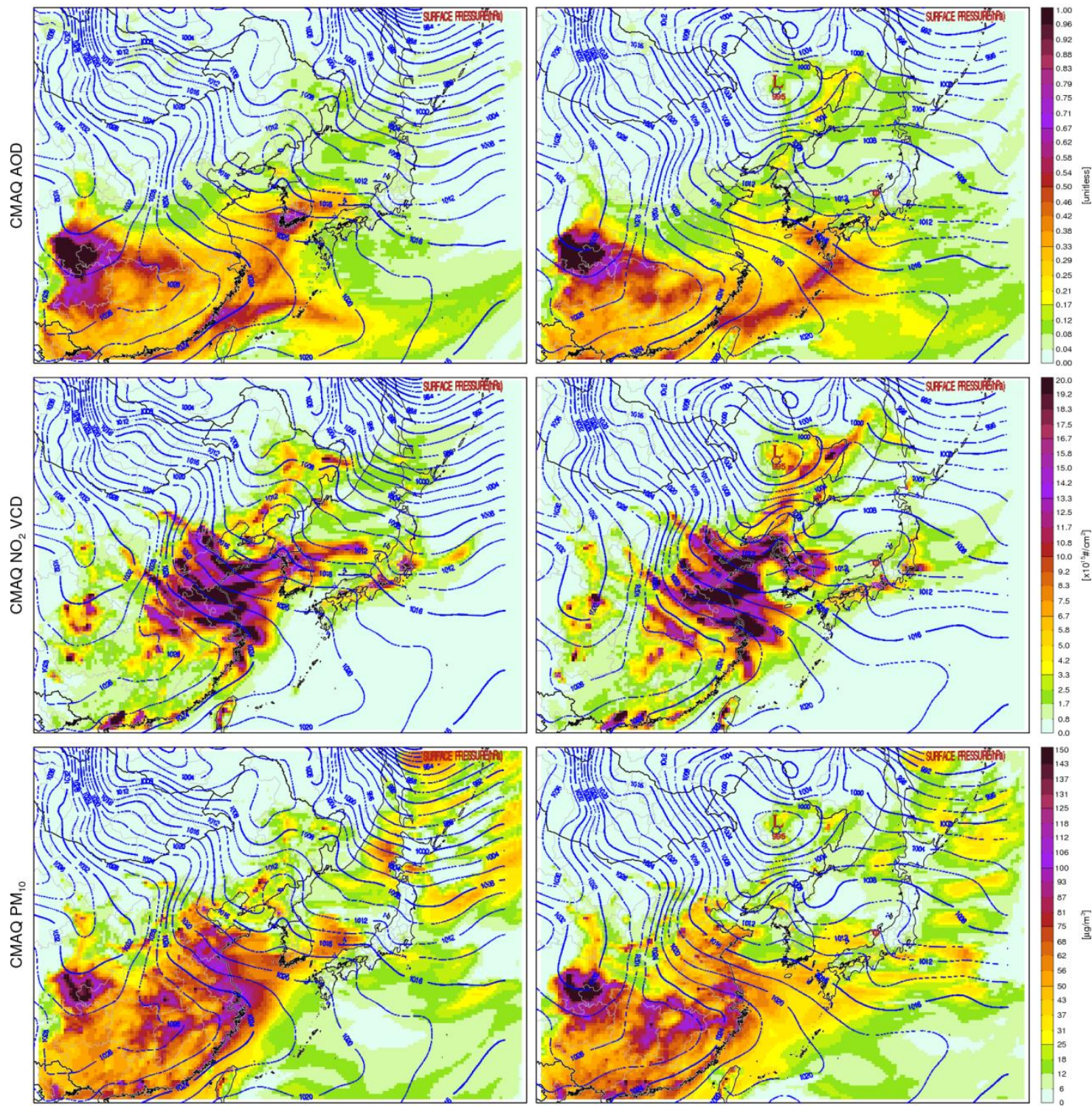

Figure 3 Continued 
Atmos. Chem. Phys. Discuss., doi:10.5194/acp-2016-673, 2016

Manuscript under review for journal Atmos. Chem. Phys.

Published: 9 September 2016

(c) Author(s) 2016. CC-BY 3.0 License.
Atmospheric

Chemistry

and Physics

Discussions

(c) (i)

April 06, 2014
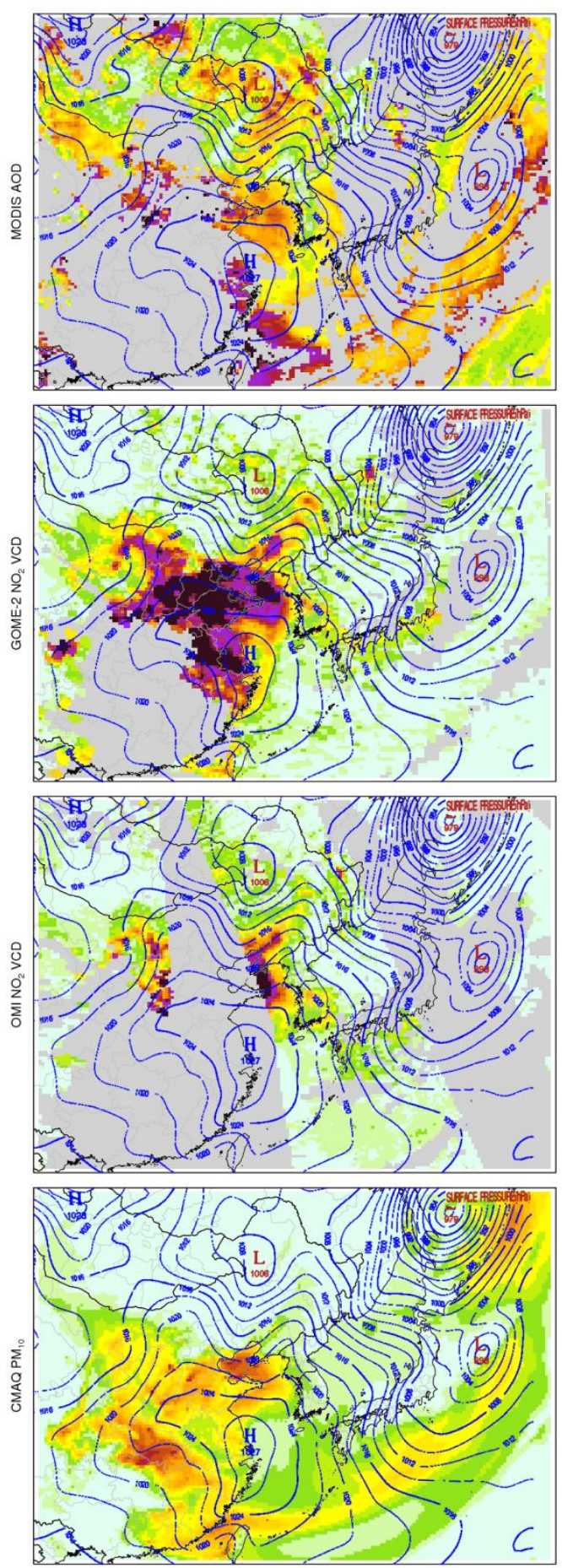

April 07, 2014
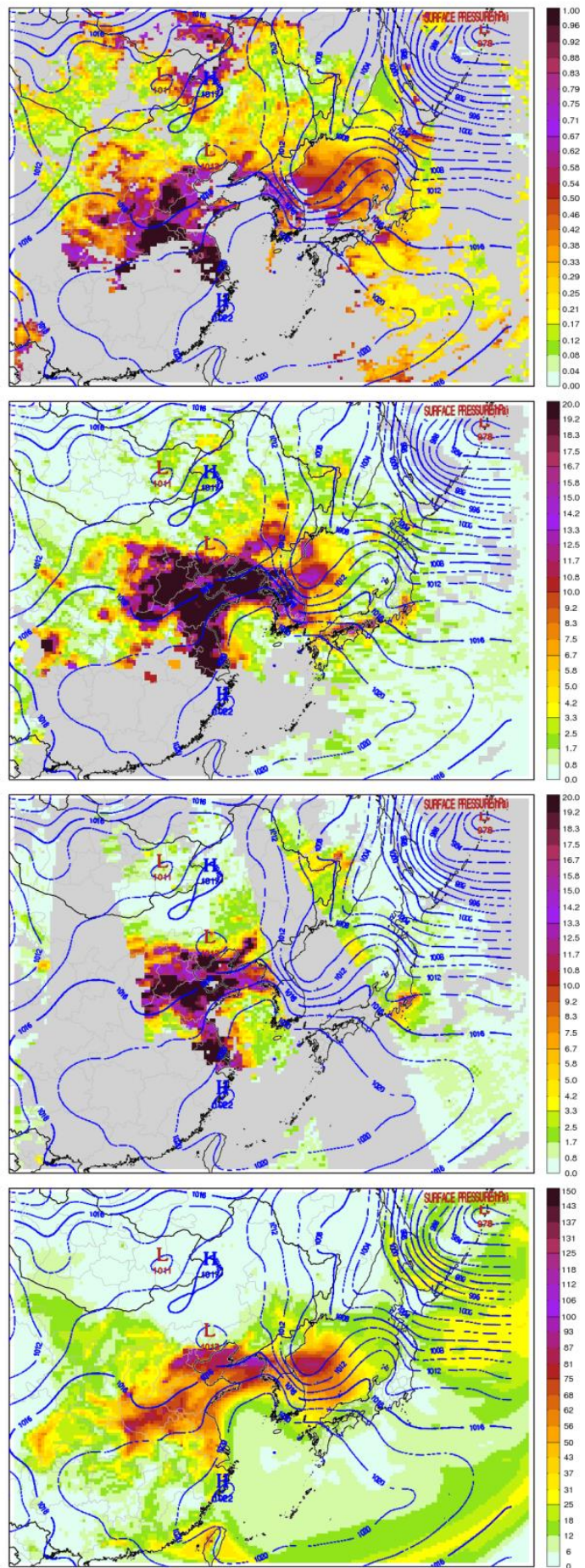

Figure 4 Case of the Siberian High expansion (Type 1; Fig. 2a) from April 6-7, 2014. Similar to Figure 3 except for a high-pressure system detached from the Siberian High. 
Atmos. Chem. Phys. Discuss., doi:10.5194/acp-2016-673, 2016

Manuscript under review for journal Atmos. Chem. Phys.

Published: 9 September 2016

(c) Author(s) 2016. CC-BY 3.0 License.
Atmospheric

Chemistry

and Physics

Discussions

(c) (i)

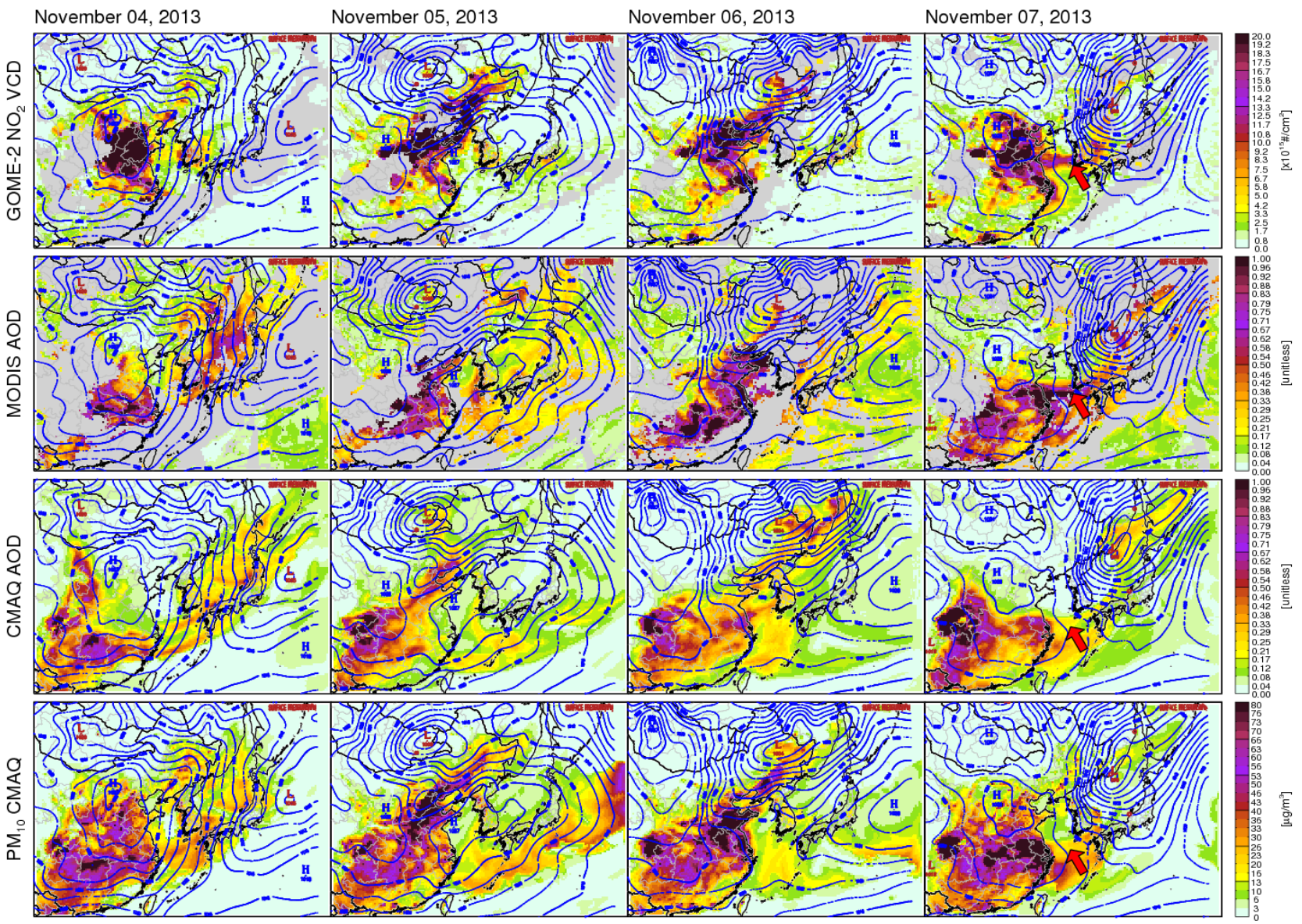

Figure 5 Case of sequential development of a high-pressure system in the South and a strong low-pressure system in the North (Type 2; Fig. 2b) from November 4-7, 2013. GOME-2 $\mathrm{NO}_{2}$ column density (top), MODIS AOD ( $2^{\text {nd }}$ row), CMAQ AOD (3 ${ }^{\text {rd }}$ row) and CMAQ surface $\mathrm{PM}_{10}$ (bottom) are shown. Red arrows indicate narrow bands of high concentration of the $\mathrm{NO}_{2}$ column, AODs, and surface $\mathrm{PM}_{10}$ as a result of air mass confined by the pushing of a passing cold front. 
Atmos. Chem. Phys. Discuss., doi:10.5194/acp-2016-673, 2016

Manuscript under review for journal Atmos. Chem. Phys.

Published: 9 September 2016

(c) Author(s) 2016. CC-BY 3.0 License.
Atmospheric

Chemistry

and Physics

Discussions

(c) $\underset{\mathrm{BY}}{(i)}$

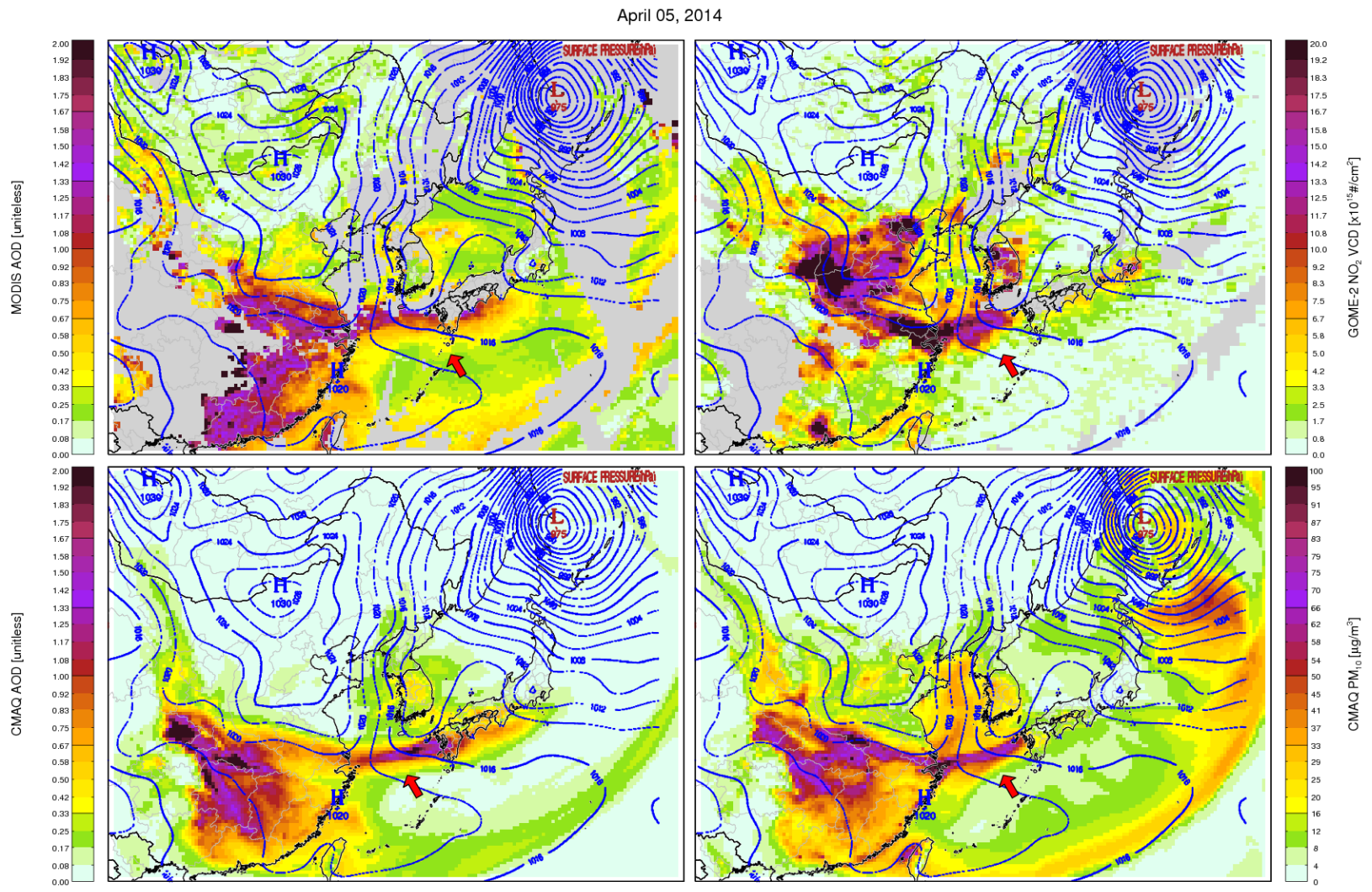

Figure 6 Narrow high-concentration bands association with cold frontal passage, shown in MODIS AOD (upper left), CMAQ

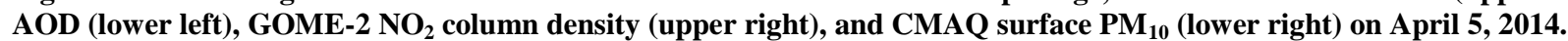


Atmos. Chem. Phys. Discuss., doi:10.5194/acp-2016-673, 2016

Manuscript under review for journal Atmos. Chem. Phys.

Published: 9 September 2016

(c) Author(s) 2016. CC-BY 3.0 License.

\section{Atmospheric \\ Chemistry \\ and Physics \\ Discussions}

(c) (1)

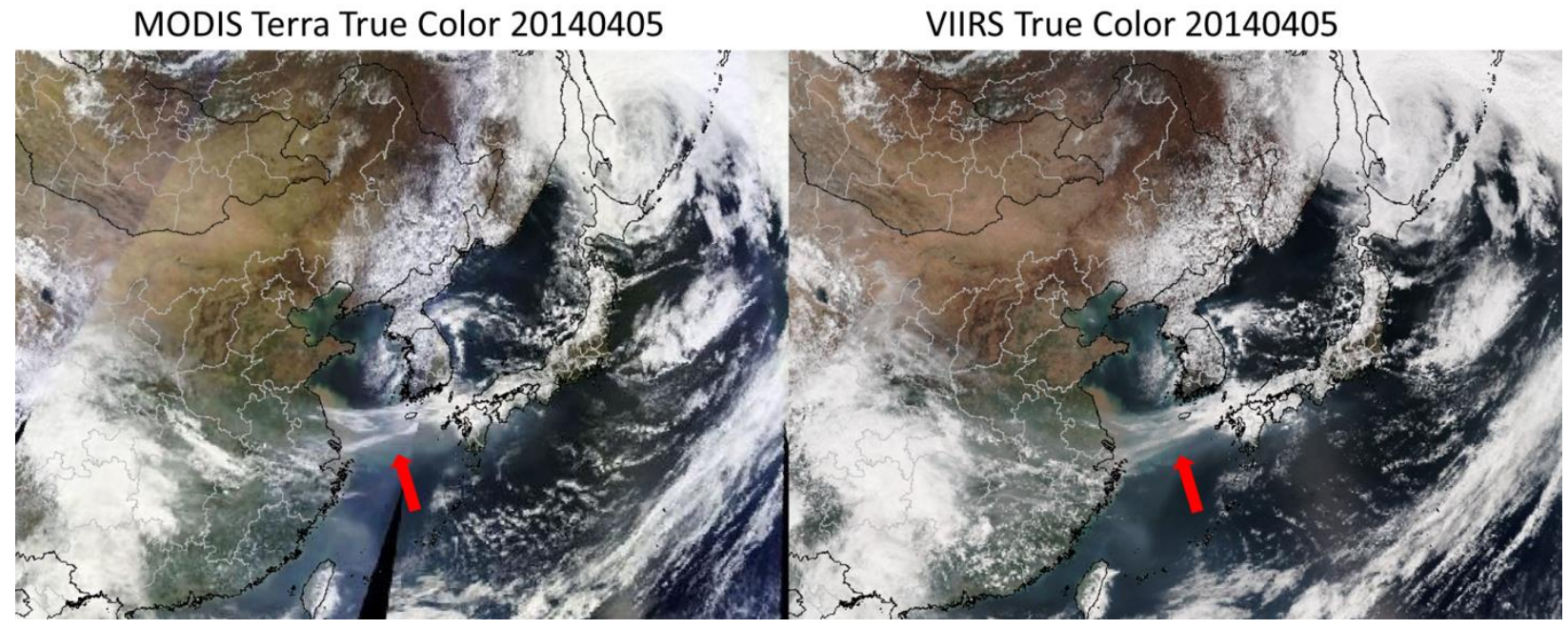

Figure 7 True color images of high concentration band as shown in Figure 6. Images are from MODIS Terra (left) and VIIRS (right). 
Atmos. Chem. Phys. Discuss., doi:10.5194/acp-2016-673, 2016

Manuscript under review for journal Atmos. Chem. Phys.

Published: 9 September 2016

(c) Author(s) 2016. CC-BY 3.0 License.

\section{Atmospheric}

Chemistry and Physics

Discussions

(c) (i)
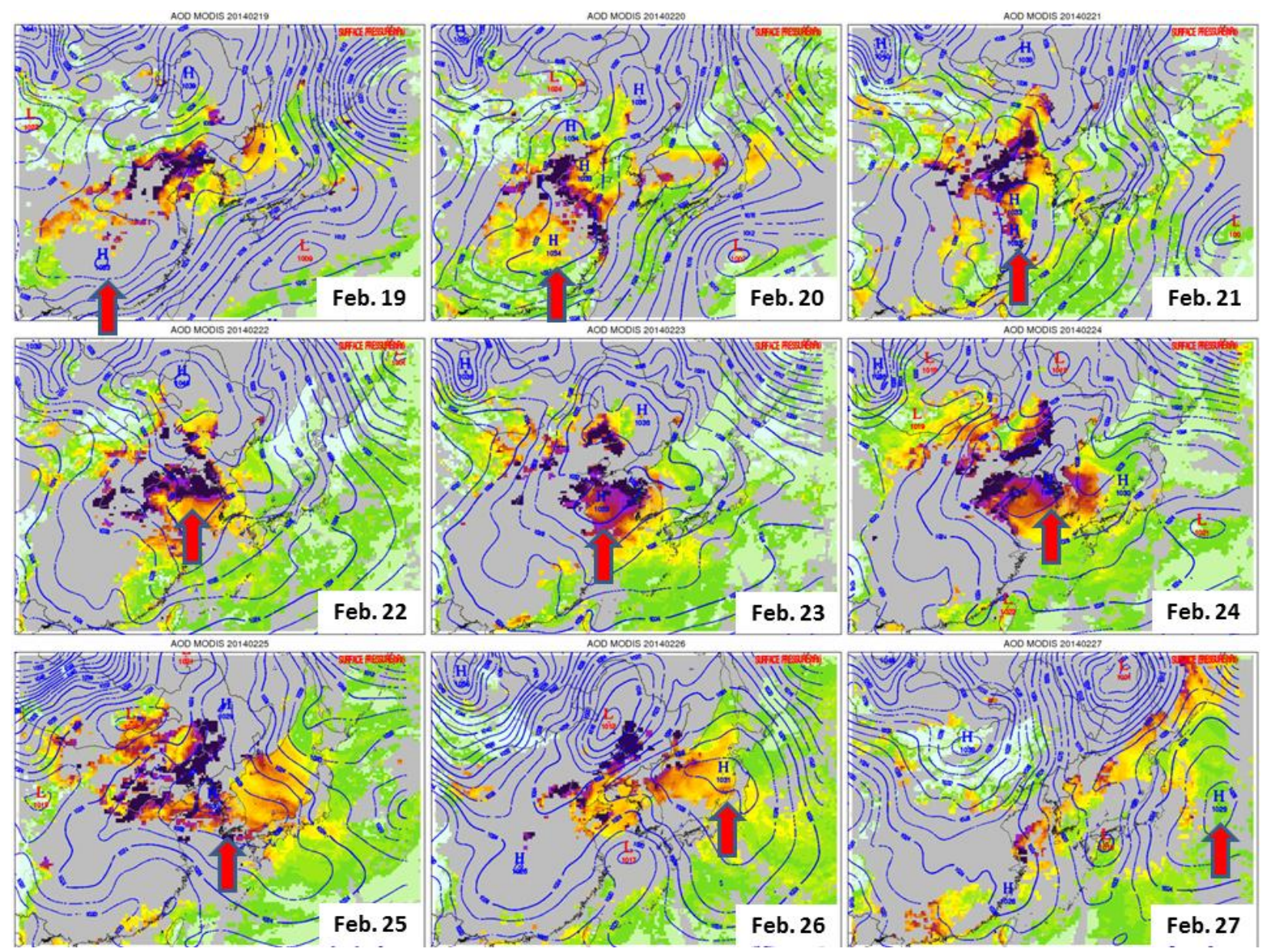

Figure 8 Case of a slow/stagnant high-pressure system with corresponding MODIS AOD (Type 3; Fig. 2c) during February 19-27, 2014. Red arrows indicate the location of the stagnant high-pressure system. 
Atmos. Chem. Phys. Discuss., doi:10.5194/acp-2016-673, 2016

Manuscript under review for journal Atmos. Chem. Phys.

Published: 9 September 2016

(C) Author(s) 2016. CC-BY 3.0 License.
Atmospheric

Chemistry

and Physics

Discussions

(c) (i)
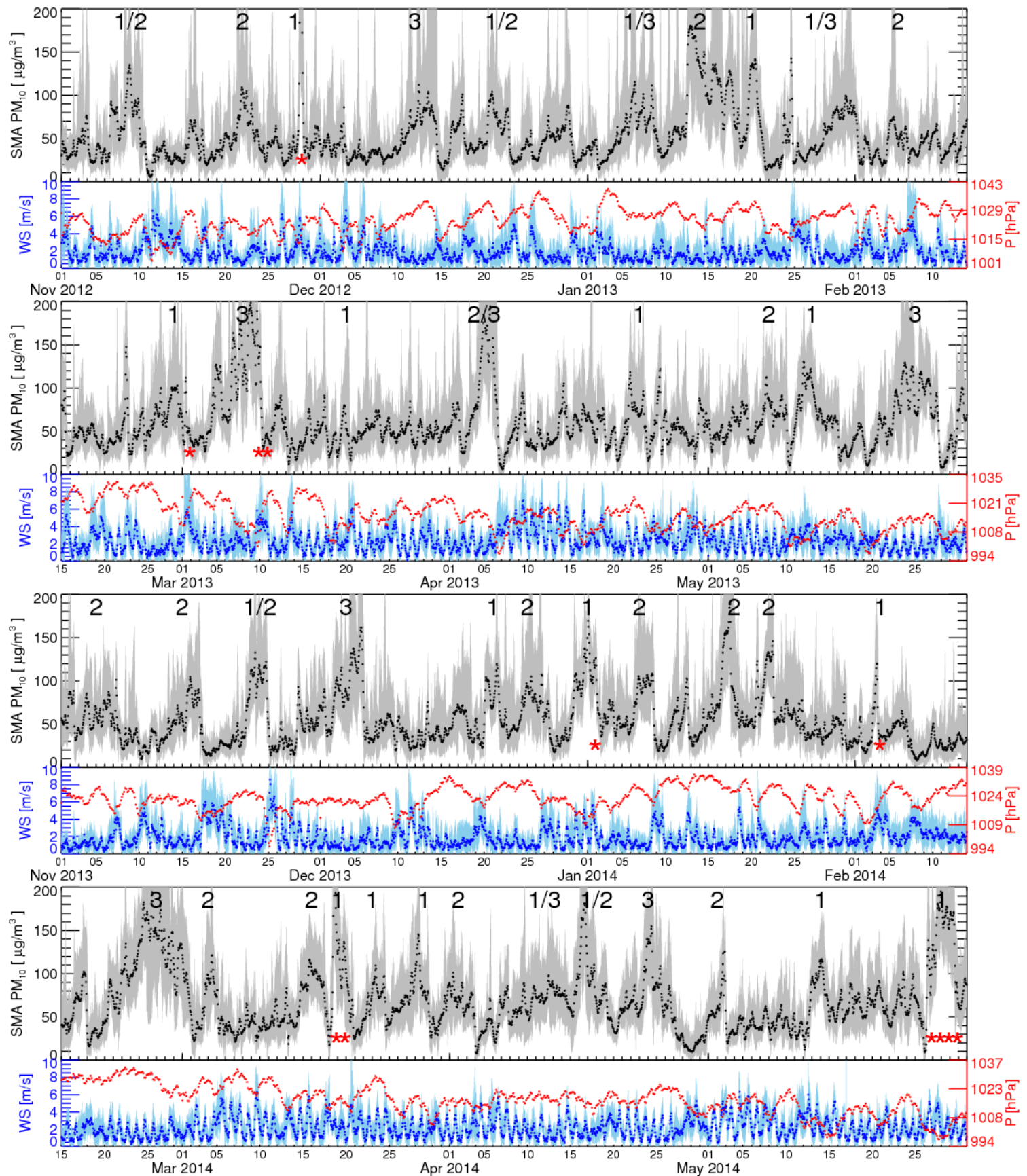

Figure 9 Time series of surface $\mathbf{P M}_{10}$ concentration, 2-m wind speed, and surface pressure in the SMA during the two cool seasons, November 2012 to May 2013 and November 2013 to May 2014. Asian Dust events, as defined by KMA, are marked with (*). Numbers (1-3) indicate pollutant transport patterns types, as described in the context. 
Atmos. Chem. Phys. Discuss., doi:10.5194/acp-2016-673, 2016

Manuscript under review for journal Atmos. Chem. Phys.

Published: 9 September 2016

(c) Author(s) 2016. CC-BY 3.0 License.

\section{Atmospheric \\ Chemistry \\ and Physics \\ Discussions}
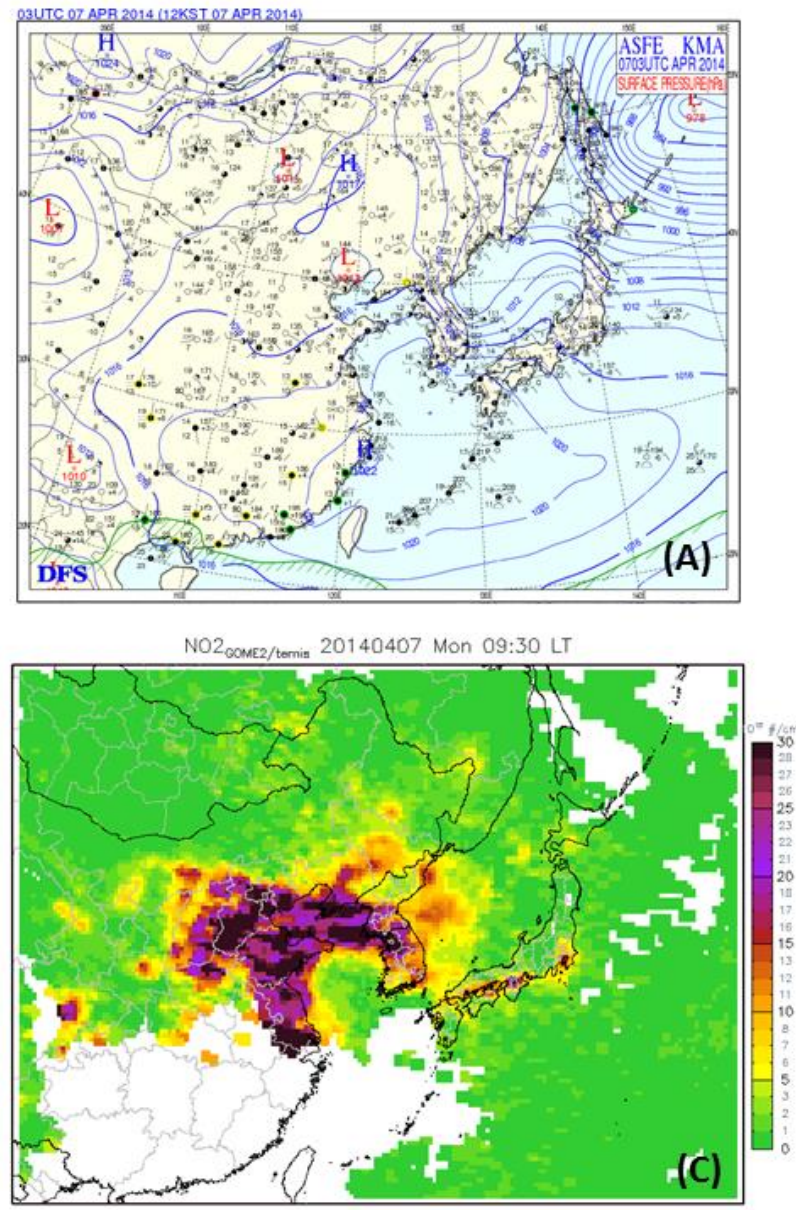
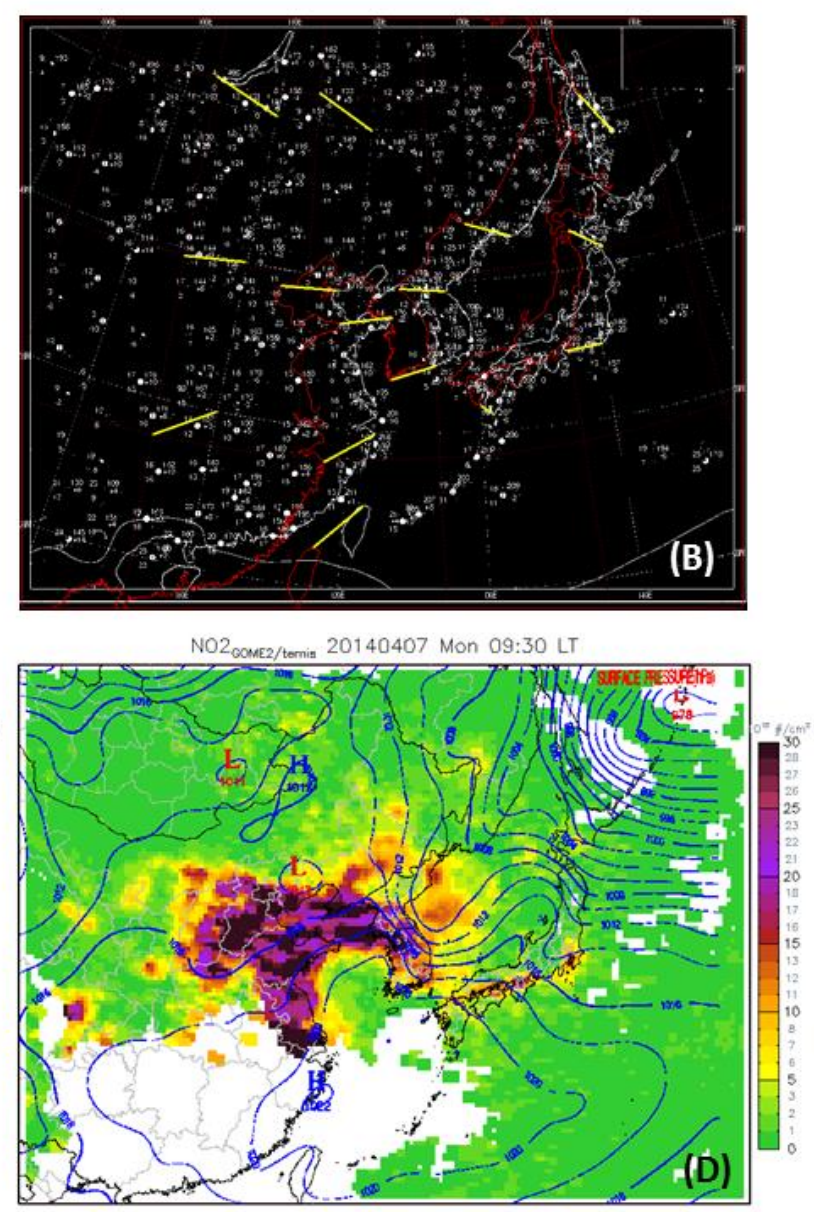

Figure 10 Example of georeferencing procedure to overlay (a) surface weather chart to (c) GOME-2 $\mathrm{NO}_{2} \mathrm{VCD}_{\text {plot. }}$ One-time linking step required as shown in (b), and the combined plot is shown in (d). 